\title{
Uma análise crítica do direito à diferença
}

\section{Ciladas da diferença.}

PIERUCCl, Antônio Flávio.

São Paulo: 34, 1998. 222p.

Muito pouco se discutem os efeitos políticos e as conseqüências sociais de um determinado tipo de discurso, típico dos movimentos sociais de esquerda: o discurso do "direito à diferença". Ciladas da diferença, de Antônio Flávio Pierucci, é um livro que se presta a fomentar esse debate, e como o próprio título nos sugere, aponta os dilemas e os riscos de se eleger a atenção social à diferença como um princípio das lutas políticas.

Formalmente, o livro se divide em sete capítulos, distribuídos em duas partes, e resulta da compilação de artigos já publicados pelo autor em periódicos, conferências e capítulos de outros livros. Grande parte dos argumentos desenvolvidos por Pierucci tem o apoio de dados empíricos colhidos e analisados pelo autor em pesquisas anteriores, tendo como sujeitos pessoas pertencentes às camadas médias da cidade de São Paulo. A seguir, destaco os principais temas e teses em que o autor se detém, sem necessariamente seguir a ordem em que eles aparecem. Interessa mais, para os fins desta resenha, sublinhar a necessidade de analisarmos com maior cuidado o "discurso da diferença". Vale dizer, antes de tudo, que o autor não está questionando a diferença de fato, a condição singular de cada pessoa, mas a emergência de "novos" modos de se exigir o reconhecimento político e social da diferença.

O primeiro argumento desenvolvido por Pierucci é na verdade uma lembrança, encoberta pelo "charme" e pelo "fascínio" dos discursos de esquerda que afirmam o primado da diferença. Trata-se do fato de que a obsessão pela diferença é originalmente uma característica da direita política. É a direita que, historicamente, nega-se a aceitar o princípio de igualdade entre os seres humanos, justificando a desigualdade pelo fato "concreto" das diferenças entre os grupos coleti- vos étnico-culturais. Assim, tudo o que parece inovador nos discursos da diferença é na verdade um retorno a uma velha pauta de princípios da direita. O próprio racismo está centrado na ênfase à diferença, no caso, rejeitando-a e a indicando como a fonte "natural" da desigualdade social. Em razão disso, Pierucci assinala a aproximação dos discursos de esquerda que enunciam o "direito à diferença" aos velhos argumentos da direita, pelo fato de ambos apoiarem a diferença em um dado natural e sensível: o corpo.

O contraste entre a direita e a esquerda em relação à diferença se realiza pelo fato de que, para a segunda, não há razão em se optar ou pela igualdade ou pela diferença. Supõe-se, inclusive, nos meios intelectualizados de esquerda, que a desigualdade nada tenha a ver com a diferença. Para Pierucci, é nesse ponto que reside o equívoco que constitui uma das "ciladas" da diferença: a crença de que a defesa da diferença possa se desvincular das relações de valor que fundamentam a desigualdade. A partir do antropólogo Luis Dumont, o autor demonstra que não há como enfatizar a diferença sem afirmar ao mesmo tempo uma distinção de valor. Por essa razão, anunciar a condição de "diferentes, mas iguais", ou de "igualdade na diferença" é correr o risco de eleger uma luta possível mais no discurso do que na realidade. Nesse sentido, a conclusão do autor é que anunciar o "direito à diferença" é uma postura mais coerente na direita do que na esquerda política.

Estranha Pierucci que certos movimentos identitários de esquerda tenham como mote a ênfase numa diferença sensível (cor da pele, sexo etc), através de discursos pautados em políticas do corpo que lembram o peso fornecido pela direita aos dados naturais. Para o autor, a esquerda sempre esteve mais próxima das lutas pela igualdade, que implicam uma postura de abstração das particularidades, enquanto a direita é que tem enfatizado os dados concretos oferecidos à esfera sensível. Se antes era a direita que exigia a manutenção de mecanismos de pertencimento dos sujeitos que valorizam dados naturais, agora é a esquerda que defende políticas do corpo que se utilizam dessas estratégias políticas.

Pierucci esforça-se em elucidar seus argumentos à luz da análise de acontecimentos de 
nível internacional e que demonstram como podem se evidenciar as "ciladas da diferença". Um deles é a efervescência política e conceitual gerada no campo jurídico norte-americano através do caso Sears, onde duas posições opostas de diferentes vertentes do movimento feminista entraram em confronto, no intuito de verificar a presença de discriminação sexual nos processos de contratação de uma grande empresa varejista nos Estados Unidos. Entre a demanda política pela igualdade dos sexos e a emergência do discurso da "diferença" da experiência das mulheres, engendrou-se um debate histórico de repercussões até hoje discutidas.

Cumpre destacar que uma das autoras feministas enquadradas por Pierucci como representante do "discurso da diferença" é a historiadora Joan W. Scott. Essa autora, analisando os dilemas do feminismo a partir do caso Sears sob a ótica pósestruturalista, desconstrói o pensamento dicotômico que opõe a igualdade à diferença. ' Para ela, tais aspectos, no contexto das relações de gênero, estão em uma relação de interdependência onde "a igualdade não é a eliminação da diferença, e a diferença não exclui a igualdade" (lbid. p. 209). Embora aponte os riscos que a ênfase na diferença incorre, como o da naturalização dessa condição, Scott propõe que não se perca o poder analítico dessa categoria. Seu argumento aponta a relevância de se insistir no caminho da diferença como a principal forma de se superar o absolutismo do masculino. Na análise de Scott, o reconhecimento da diferença e o resgate das "experiências das mulheres" são estratégias políticas necessárias ao movimento feminista.

Pierucci se contrapõe ao ponto de vista da autora, mostrando ser difícil ir a fundo na lógica diferencialista sem incorrer em algum modo de discriminação. A tentativa de conciliar a luta pela igualdade com a defesa do "direito à diferença", para o autor, ignora a impossibilidade de se separar a diferença dos atributos sociais de valor. Nesse sentido, aprofundar esse debate inclui considerar que "o jogo político é também uma guerra semântica" (p. 43).

É na tese da produtividade da diferença que o autor sofistica sua análise, mostrando o quanto a diferença se destina a gerar mais diferença. $O$ discurso do direito à diferença tem como pauta principal a contraposição ao princípio universalista moderno, defendendo que a condição específica de alguns sujeitos não está contemplada nesse âmbito social e político. É o caso do movimento feminista de "segunda onda", nos termos do autor, cuja ênfase na não adequação dos "direitos humanos" à condição da mulher resulta por exigir o "direito à diferença". Afirmando que os sujeitos são sexualmente engendrados, essa vertente do movimento feminista aponta a inexistência do sujeito abstrato dos direitos humanos e a necessidade de se incluir a "diferença" das mulheres nesse contexto. É nesse ponto que se produz a grande "cilada da diferença" proposta por Pierucci, instalando-se um dilema entre abstrato/universal e concreto/ particular. Esse discurso, ao se desvincular do compromisso com a abstração das particularidades, assume a demanda pelo reconhecimento e pela valorização de novas diferenças que atravessam seu caminho. No exemplo de Pierucci, tão logo se observou a diferença das mulheres, emergiram as "diferenças de dentro": as mulheres não-brancas passaram exigir que se contemplasse sua diferença, não mais de gênero, mas de etnia. $O$ argumento permanece o mesmo: a noção de "mulher universal" é criticada como mera abstração, válida apenas para as mulheres brancas. É próprio da diferença, portanto, abrir demandas pelo aparecimento de outras diferenças, sempre pautadas no que é no fundo um dado natural e visível. $O$ aspecto irônico de todo esse processo, para o autor, traduz-se no fato de que são esses mesmos discursos os primeiros a se contraporem a todo tipo de essencialismo.

No apogeu da produção da diferença Pierucci identifica as perspectivas que se anunciam como "multiculturalistas", tão comentadas no meio acadêmico atual. Junto com as críicas pósmodernas ao sujeito universal, afirma-se cada vez mais o primado da diferença, onde as "múltiplas etnicidades", as "múltiplas culturas", são categorias de análise que caracterizam todo o processo gerado pela valorização da diferença no mundo contemporâneo. $O$ autor resume esse processo dizendo que se trata do desdobramento da igualdade na diferença e desta última nas diferenças presentes em todo tipo de "múltiplos" que se defende nas teorias pós-modernas. Por isso, diz Pierucci, "a diferença jamais é uma só, mas sempre já-plural, sempre sobrando, muitas; sem unidade e sem união alguma possível" (p. 150).

Pierucci não se arrisca tão explicitamente a apontar algum caminho, mas dá indícios de que um modo de superarmos os dilemas da diferença é reconstruir o "geral", sem essencializar as diferenças. Reconhece o autor que, a despeito de seus efeitos perversos, o discurso da diferença tem 
produzido interessantes formas de emancipação humana. No entanto, ao denunciar os labirintos que construímos pela ênfase na diferença, alertanos contra as ciladas que possamos eventualmente cair sem considerar as implicações dos lemas que embandeiramos.
I SCOIT, Joan. W. "Igualdade versus diferença: os usos da teoria pós-estruturalista." Debate Feminista (Cidadania e Feminismo), nº especial, 2000, p. 203-222.

\section{Para a re-inscrição das estórias do gê- nero no romance português contempo- râneo}

\author{
Gênero e história no romance por- \\ tuguês contemporâneo: novos su- \\ jeitos na cena contemporânea
}

\section{SCHMIDT, Simone Pereira.}

Porto Alegre: PUC/RS, 2000. 215p.

É curioso que num país em que se publicou, a princípios dos anos setenta, o modelo pioneiro de escrita feminista, intitulado Novas Cartas Portuguesas, ainda se registre uma quase completa ausência de uma crítica literária voltada para a luta por uma sociedade mais justa que vem a ser, em termos latos, o feminismo. E feminismo, no singular, apesar de todas as variações e tensões que o caracterizam nas últimas três décadas, e que o texto híbrido das famosas três Marias já dramatiza. Sem querer privilegiar um ponto de vista qualquer, não imiscuído nas peias discursivas e institucionais que em Portugal têm impedido mais do que uma ou outra expressão isolada de críica acadêmica feminista, é evidente que só à distância tem sido factível levar a cabo esse labor de forma assumida e sistemática. É isso o que nos sugere o recente livro da investigadora brasileira Simone Pereira Schmidt, Gênero e história no romance português: novos sujeitos na cena contemporânea, um olhar tão distanciado quanto empático e específico sobre a emergência do sujeito feminino, ou melhor, feminista, na produção ficcional portuguesa na segunda metade do século XX.
Diferentemente de estudos temáticos centrados tão só em romances de autoria feminina ou masculina, o trabalho de Simone Pereira Schmidt põe em movimento uma complexidade de perspectivas, não só ao nível de teorização como também de análise e de ilações históricoliterárias, confrontando textos de homens e muIheres dos anos cinqüenta e dos anos oitenta. $O$ resultado não é simplesmente "uma leitura", outra mais, de textos particulares. É antes um exemplo da pluralidade de preocupações, e por conseguinte de enfoques, que a teoria crítica feminista elaborada a partir do anti-fundacionalismo pósmoderno traz à crítica literária, que equivale também a dizer à interpretação de processos históricos e culturais, neste caso portugueses. Estamos perante uma práxis feminista interdisciplinar guiada pelo objetivo de trazer para o centro dos estudos literários uma reflexão atuante em torno da política do gênero que lhes é inerente de forma profunda e difusa, mas não imutável. Daí (também) a importância de não valorizar enunciados ou figurações femininos ou masculinos, colocando-os em diálogo crítico ou, para usar o conceito bakhtiniano que engloba a metodologia do presente estudo, um "cruzamento" de vozes, de ideologemas, de tempos, espaços e locais de enunciação. O que oferece não poucas surpresas, se não à teoria crítica feminista per se, certamente ao entendimento de como o romance português contemporâneo é locus de codificação, transformação e reinvenção de identidades convencionais do gênero.

Gênero e história no romance português contemporâneo surpreende primeiro pelo rigor da problematização teórica que a autora elabora de antemão, e à luz da qual vai cerzindo posterior- 
mente suas análises; em segundo lugar, pela escolha dos quatro romances que integram o corpus primário de investigação. Representando não só dois grandes momentos da história do romance português contemporâneo, como também dois grande autores e duas grandes autoras, esses romances são A sibila (1954), de Agustina Bessa-Luís, Aparição (1959), de Vergílio Ferreira, Notícia da cidade silvestre (1984), de Lídia Jorge, e História do cerco de Lisboa (1989), de José Saramago. Cada texto é objeto de minuciosa análise na procura do modo como seu discurso releva histórias do gênero sexual, incluindo as relações de poder em que se apóiam, e sobretudo como esse discurso traz à tona transgressões ao domínio difuso dessas estórias. Colocam-se assim em evidência não só junções de polifonia e ambivalência discursivas como também a insinuação, e mesmo a auto-afirmação, de sujeitos liminares femininos (mas também não só, como é o caso de Raimundo Silva, da História do cerco de Lisboa). A definição de Boaventura Sousa Santos relativa à identidade de fronteira de Portugal é nesse sentido propícia, indo ao encontro de sugestões teóricas de Linda Hutcheon e Donna Haraway sobre identidades "excêntricas" ou estratégias recombinatórias (0 "cyborg") típicas de sujeitos não hegemônicos pósmodernos. Esse olhar simultaneamente abstratoteórico, especificado num argumento, ou fonte secundária de fundamento local, torna possível a recuperação de vozes e identidades que, não se podendo considerar típicas de um tempo dito pósmoderno, continuariam enterradas num ou noutro discurso hegemônico, como acontece com Sofia em Aparição, personagem que Schmidt lê contra o grão da voz narrativa de Vergílio Ferreira.

Embora não se detendo em maiores detaIhes historiográficos, sociológicos ou antropológicos, o estudo da face cambiante do gênero nos referidos romances é desenvolvido a partir de amplos parâmetros contextuais atentos a condicionantes de tempo, espaço e inserção filosófico-literária, antes e depois da grande baliza representada pela revolução de 25 de abril de 1974. Os trinta anos que separam as publicações de A sibila e Notícia da cidade silvestre, por um lado, e as de Aparição e História do cerco de Lisboa, por outro, assistem a não poucas reviravoltas na sociedade portuguesa, que a autora associa corretamente a um lento processo de modernização das estruturas sociais, econômicas e mentais precipitado no período pós-revolucionário com a entrada de Portugal na corrida neo-liberalista do mercado europeu, de que o romance de Lídia Jorge dá notícia. Com relação à perda de antigas utopias democráticas e à dissolução de algumas "grandes verdades" celebradas com o 25 de abril, talvez valesse a pena referir o efeito que o golpe contra-revolucionário de novembro de 1975 teria nos romances dos anos oitenta. Uma ausência menor, que de resto não altera as sensíveis interpretações apresentadas à luz do mais amplo panorama histórico-cultural.

Após seu tratamento isolado em quatro subcapítulos, formando a parte central do livro, os quatro romances são depois confrontados ou "cruzados" num terceiro capítulo. Este é constituído por uma série de análises intertextuais focalizadas em torno de constantes discursivas vindas à tona nas análises anteriores. Essas constantes, que Schmidt denomina "motes", são "Espelhos narrativos", "Subjectividades", "O outro", "Relações do gênero" e "Poéticas de localização". Mais do que síntese ou conclusão, que também não o deixam de ser, ficam assim traçadas novas linhas de leitura. Estas funcionam como pontes de ligação entre textos teóricos e ficcionais, entre vozes "outras" recusando qualquer outra unidade (ou formação de comunidade) que as reduza a um qualquer centro ou mesmo neutralizador de diferenças. Será esse o convite que o livro de Schmidt lança a posteriores incursões teórico-críticas relevantes aos estudos feministas do gênero a acontecer (e com que urgência) no campo específico do romance português contemporâneo.

O penúltimo capítulo da História do cerco de Lisboa (1989), de José Saramago, põe em cena um breve diálogo que poderá servir de fecho para a presente resenha, na medida em que refrata uma das transformações epistemológicas e políticas mais palpáveis vindas da história do feminismo na época contemporânea. Nessa cena, Maria Sara, uma figura de mulher independente, e a vários níveis "idealizada", como bem o afirma Schmidt, imputa o problema da luta pelo poder que reduz as relações entre homens e mulheres à "macheza", acabando por perguntar ao seu interlocutor se os homens "alguma vez se decidirão a ser naturais na vida". A tal provocação, o "feminino" ou "ex-cêntrico" revisor, Raimundo Silva, responde: "Nenhum ser humano é natural". Se bem que ninguém precise ser licenciado para conhecer na pele essa evidência, não há dúvida de que sua articulação e problematização teórica se devem, na época contemporânea, sobretudo ao impulso de uma série de lutas locais e 
multifacetadas pela emergência civil, cultural e política das mulheres como sujeitos libertos de mitos patriarcais de femininidade. Mais à frente no diálogo é a vez de Maria Sara negar toda e qualquer divisão dicotômica entre as pessoas, postulando o ideal resistente da negatividade — o "não" — como forma última de afirmação da subjetividade contra tudo aquilo que a oprima e silencie.

Ora, as relações de gênero na vida privada são apontadas no estudo de Schmidt como índice, não simples reflexo, de tempos-espaços marcados ora pela repressão e pelos obscurantismos salazaristas, ora pela desilusão no termo da euforia revolucionária e pela nova esperança no ser humano que se precisa continuamente reinventar.
O caráter movediço e polivalente desses índices é iluminado para sugerir sua historicidade radical em relação ao presente, o da construção do texto crítico. É aqui o lugar onde o "não" de muitos sujeitos renascidos ou redescobertos pelo sentido crítico da autora reverbera com vistas ao "sim" para lá de seu tempo e espaço. Eis o que nos vem oferecer Gênero e história no romance português: novos sujeitos na cena contemporânea. É de celebrar a atitude distanciada e, contudo, de comprometimento crítico e afetivo com uma literatura nacional em tudo também "ex-cêntrica" no contexto das literaturas européias, e não só.

ANA PAULA FERREIRA

\section{"Novas" violências assolam o cotidiano}

\section{Assédio Moral. A violência perver- sa no cotidiano}

HIRIGOYEN, Marie-France.

Rio de Janeiro: Bertrand Brasil, 2000. $224 p$.

Nesse livro notável, Marie-France mostra como se processa um tipo de violência, que considera perversa, no cotidiano de nossas vidas. Permite-nos observar pelo "olho da fechadura" o estabelecimento e a evolução de relações interpessoais caracterizadas pela violência psicológica em diferentes espaços institucionais.

A autora concentra-se na definição e na análise da violência perversa, ou assédio moral, enfatizando que determinados indivíduos podem exercer sobre os outros uma verdadeira e demolidora estratégia de produção de poder, no sentido da dominação, com o objetivo de eliminar aqueles que foram escolhidos como vítimas. Segundo a autora, essa violência emerge como uma estratégia de poder totalitário, pois a dominação que se pretende implica a destruição/anulação do outro diferente.

A análise desses relacionamentos invoca diferentes espaços sócio-institucionais: no mundo do íntimo, a família; no espaço público, a empre- sa. Na família, a autora analisa a violência perversa no relacionamento entre pais e filhos e entre os casais; na empresa, focaliza o relacionamento entre chefias e subordinados e entre os colegas. Cada relacionamento é discutido teoricamente a partir de casos clínicos. Em três capítulos - "A violência perversa no cotidiano", "A relação perversa e seus protagonistas" e "Conseqüências para a vítima e responsabilidade" - Marie-France coloca a nu o que denomina violência privada (na família) e na empresa, analisa as características psicológicas dos protagonistas do drama (o perverso narcísico e sua vítima) e finalmente mostra as conseqüências desse tipo de relacionamento para as vítimas, orientando sobre as estratégias que podem ser utilizadas para se livrar dessa situação.

O poder, como catalisador das relações interpessoais nos diferentes espaços institucionais, não é discutido pela autora; ele é invocado e se faz presente como um eixo da análise, embora não seja suficientemente problematizado. Entretanto 0 discurso da autora deixa transparecer a presença de um ethos masculino no exercício do poder totalitário nessas instituições, especialmente no espaço familiar, já que seus exemplos clínicos de vítimas da perversão entre casais são sempre mulheres.

Logo na introdução, a autora alerta para o perigo que pode se esconder nos "encontros" com os semelhantes. Qualquer um de nós pode ser interpelado por um outro que poderá desejar nos 
destruir psicologicamente e quem sabe fisicamente. Como já foi dito, a autora chama esse processo destrutivo de assédio moral. Considera-o uma forma de violência indireta perante a qual a sociedade ainda permanece "cega". Em função disso, o livro tem o tom forte da denúncia e consegue transmitir, na análise dos protagonistas do drama, um certo maniqueísmo ao apontar a existência na sociedade de indivíduos bons e de indivíduos maus. Há compromisso moral e ético por parte da autora, que sem abandonar a objetividade renuncia à neutralidade, colocando-se explicitamente do lado das vítimas da violência.

A perversão moral que caracterizaria alguns sujeitos é considerada uma patologia. Fica claro que a posse de traços perversos e narcísicos é comum nos indivíduos, tanto quanto comportamentos sintonizados com esses traços são considerados normais em determinadas situações. Mas a perversão moral que distingue o perverso narcísico constitui, segundo a autora, a única forma possível de esse indivíduo se relacionar com o outro.

Uma espécie de predador, animal sedento de sangue, possuidor de uma especial sensibilidade para identificar suas presas, é apresentado como o algoz da relação: o perverso narcísico. A autora reconhece que o termo "perverso" é um tanto perturbador porque tem conotações morais, relativas a metamorfoses do bem em mal, mas aceita essa denominação em função de sua vasta experiência clínica com as vítimas do assédio moral, consideradas pela autora como verdadeiras vítimas, não como cúmplices masoquistas da relação.

Essa visão de uma vítima "realmente existente", e não de cúmplice da relação, a levará posteriormente a rejeitar todo e qualquer dogmatismo terapêutico, colocando-se do lado do ecletismo na escolha das terapias que podem ajudar a vítima a romper com a relação de dominação.

Explicitamente, a vítima constitui o objetivo de sua reflexão, embora ela dedique um espaço relativamente importante ao algoz da relação, visualizado como a encarnação do próprio mal. A autora descreve os perversos narcísicos como indivíduos possuidores de um certo magnetismo, uma espécie de carisma que os tornaria sedutores aos olhos alheios. Mas a imagem que a autora constrói desse tipo de sujeito é verdadeiramente assustadora. Trata-se de alguém que possui o poder de manipular os outros; alguém capaz de se apropriar da vida de outro: sanguessuga, vampiro. Enfim, um ser maligno, "sem vida própria", que para viver precisa da vitalidade e da energia de um outro, tido como puro, vital, afirmativo, e com uma tendência a culpabilizar-se e sentir-se desvalorizado.

Sem ingressar em demasiados detalhes (porque esse não é seu objetivo), a autora admite que o perverso narcísico é alguém que foi negado em sua individualidade, isto é, alguém que foi vitima na infância de um algoz, uma identidade ferida que por não conseguir sentir sua própria dor, inflige sofrimento aos outros.

O personagem Drácula de filme de Coppola, Drácula: Uma historia de amor, evoca essa construção do perverso narcísico, alguém que sofrendo a dor da perda do ser amado (uma relação fundamental) amaldiçoa Deus, metamorfoseando-se num vampiro vingativo e sedento de sangue que vagará pelos tempos fazendo suas vítimas, que consegue atrair porque possui um magnetismo que lhes anula a vontade. O reencontro com sua amada numa outra vida o redimirá de sua maldade, transformando-o num mortal que poderá finalmente descansar em paz. A recuperação do ser amado que evoca uma relação afetiva fundamental o levará à compreensão de sua própria dor.

Assim, tanto o filme de Coppola como o livro de Marie-France relembram que a violência na espécie humana não deriva de instintos animais, "fora de controle", mas de uma terrível dor recalcada, impossível de ser reconhecida pelo indivíduo, de uma violência que Ihe foi infligida e que o levou ao limite de sua própria negação. Drácula vaga pelo abismo da eternidade sem poder conter e sem entender seu ódio pelos outros, que se traduz na necessidade de beber-lhes o sangue/vida, condenando-os por sua vez à imortalidade e à maldade, isto é, trazendo-os a seu próprio "inferno". Ele se distingue porque, à diferença dos humanos, o espelho não reflete sua imagem, ele é vácuo. O perverso narcísico de Marie-France procura nos outros sua própria imagem; sua dor é um vácuo existencial que não consegue enfrentar.

O mal e a maldade existem, pois, na sociedade, viabilizados por indivíduos perversos que encontrarão sua redenção ou justificação numa história de vida que os fez também alvo da maldade dos outros. Uma cadeia infernal e interminável de "negados". Mas a autora não se submete às dores dos dráculas do século XXI. Seu alvo serão as vítimas atuais desses relacionamentos.

Para a autora, as vítimas nunca são pessoas frágeis. Muito pelo contrário, não é o déficit do outro que atrai os perversos, mas o inflacionado, as qualidades, o êxito, a beleza, a força, a vitalida- 
de, enfim, o que tem valor positivo na sociedade. A vítima é alguém que pode ser alvo da inveja, que tem algo que o "predador" não possui, mesmo que toda a construção do sentimento que leva à inveja se assente sobre um delírio. Ele investe a vítima de poderes que Ihe resultam ameaçadores; não suporta observar o que intui, o que é sua carência, no outro. Mas ele/a não quer possuir as qualidades do outro, simplesmente quer que 0 outro não as possua, e por isso almeja destruir esse espelho perverso, interpelando no outro aspectos negativos da personalidade. O sentimento que acompanha a inveja nesse caso é o ódio.

A estratégia de poder baseada no exercício da violência psicológica, ou assédio moral, é um processo que começa com uma fase de sedução perversa e que avança a outra de violência manifesta. Sedução, enredamento e controle, ou atração, desestabilização e submissão, são as estratégias violentas empregadas pelos "predadores" para poder destruir finalmente o outro. O prazer do predador é o sofrimento do outro; mas esse outro deve estar à altura, isto é, deve resistir tanto quanto responder às provocações do perverso. A resposta violenta da vítima o enche de regozijo, permite o espelhamento de sua própria maldade.

Talvez a fase mais importante desse processo seja a do enredamento e controle, quando uma verdadeira estratégia de guerra será desenvolvida pelo predador. Ele/a procurará desestabilizar psicologicamente sua vítima para impedi-la de reagir. A forma eficaz para conseguir isso seria a recusa à comunicação. Os não ditos, os silêncios, os gestos, a utilização de outras formas de comunicação que permitem o estabelecimento da ambigüidade, da confusão, serão freqüentes. O objetivo é impedir a reação da vítima, com base na produção de um ambiente confuso, que a leve à incerteza, à insegurança, a dúvidas com relação ao que acontece com o outro e com ela mesma. Deseja que o outro se sinta culpado pela relação, que sinta remorso por suas reações, que serão sempre por ele/a consideradas como "fora de lugar", exageradas, e assim por diante.

Importante mencionar que a autora coloca a nu um mundo de violências subterrâneas, extremamente trágico, porque geralmente invisível. Uma violência geralmente sem sangue, sem marcas visíveis. Humilhação, desvalorização, agressões veladas, subentendidos, um caminho que conduzirá a vítima a uma crise de identidade e à doença.

Podemo-nos perguntar, entretanto, se essa análise do assedio moral, de seus protagonistas e dos contextos sócio-institucionais não exigiria uma contextualização histórica e cultural mais apropriada. É certo que a autora parece tentar suprir essa carência estabelecendo mediações, que podem ser tidas como insatisfatórias, entre o excesso de individualismo identificado na sociedade atual e o estabelecimento desse tipo de relações, ou talvez mais, a tolerância para com esse tipo de violência, que existe atualmente nas empresas, devido a fenômenos como o desemprego, que geram medo nos trabalhadores e nas trabalhadoras, que por isso se submetem ou se transformam em cúmplices do algoz. Enfim, breves referencias são feitas a aspectos sócio-econômicos, culturais etc. Mas não se constroem mediações entre esses fenômenos psicológicos e o tipo de sociedade que os acompanha. É como se a subjetividade, seja a do algoz, seja a da vítima, não fosse construída num espaço histórico singular. É por isso que a autora não consegue explicar porque, na relação de casais, geralmente as vítimas são as mulheres. Ela não enfrenta o fato gritante de que a perversão narcísica masculina acontece numa sociedade em que prevalecem os valores do machismo, ou mais ainda, em que os machistas se vêem cada vez mais acuados perante a superioridade mostrada pelas mulheres em muitos dos espaços sociais. A negação do outro, o desconhecimento de sua diferença, tem uma base valorativa. No caso dos valores machistas, sua interiorização leva à negação do outro, à desvalorização, à humilhação, a uma espécie de anulação - um comportamento socialmente construído há até pouco tempo bem aceito.

O machista pode ser considerado um perverso narcísico? Ou, o quanto, ou como, os valores machistas reforçam ou possibilitam o surgimento dessa patologia? O quanto os atributos ditos femininos transformam as mulheres em presas fáceis dos perversos? Qual a mediação que existe entre, de um lado, a relação de dominação/poder que os homens estabelecem com as mulheres, e que é social e culturalmente construída, e, de outro, a violência perversa entre casais? Qual a relação entre a emancipação feminina, no sentido da produção de novos valores e atributos, e a violência perversa do homem com relação à mulher?

Outras interrogações se impõem. Há sociedades caracterizadas pela perversão narcísica, isto é, que negam as diferenças individuais, cujas instituições permitem a manipulação, a mentira, que levam a população a confusão, à ambigüidade, 
impedindo a reação à violência infligida? Há sociedades em que esses processos são mais explícitos, ocorrem com maior freqüência?

Enfim, o livro de Marie-France é fundamental pelos menos por duas razões. Primeiro porque desnuda com maestria o universo quase invisível da violência psicológica nas instituições, num momento histórico em que o incremento de outros tipos de violência na sociedade ocupa a atenção tanto de cientistas quanto de políticos, intro- duzindo assim uma nova agenda nas discussões. Segundo porque estimula a refletir sobre a violência psicológica nas organizações do mundo do trabalho e sua relação com as novas formas de gestão do trabalho, uma questão da maior importância para os administradores preocupados com a gestão dos recursos humanos nas empresas.

\section{Modos de ser, modos de ver la estirpe de mnemosine}

\author{
Refúgios do eu: educação, histó- \\ ria, escrita autobiográfica.
}

\author{
MIGNOT, Ana Chrystina Venancio, \\ BASTOS, Maria Helena Camara e \\ CUNHA, Maria Teresa Santos. (Orgs.)
}

Florianópolis: Mulheres, 2000. 239p.

Al explicar la ilustración escogida para la portada del libro Refúgios do eu, un grabado del siglo XIX que nos presenta a una niña volcada sobre el papel en acto de escribir, las coordinadoras del volumen, Ana Chrystina Venancio Mignot, Maria Helena Camara Bastos y Maria Teresa Santos Cunha, profesoras de distintos postgrados en Educación en diferentes universidades de Brasil, apuntan que dicha imagen "sugere que ao se debruçar sobre os papéis ela se debruça sobre si mesma" (p. 17). Una sugerencia que tiene todas las cartas para ser perfectamente verosímil, toda vez que cada ejercicio de escritura personal es, en realidad, una suerte de viaje al interior de uno mismo. Incluso, como a veces se ha dicho, la ocasión para exorcizar nuestros propios fantasmas y hacerlos visibles.

Conforme añaden las coordinadoras, la rapariga del grabado pudo enfrentarse a la página en blanco tanto para dejar en ella su visión del mundo como para depositar su vida o una parte de la misma, para confesar sus temores o para revelar algunos de sus secretos, quién sabe si hasta los más íntimos. Circunstancias que hacen de cada evento de escritura el lugar donde se experimenta el secreto encuentro del sujeto escritor, el refugio del yo, justo cuando éste se hace visible mediante la corporeidad que le otorga el texto. He aquí buena parte de las interrogaciones, aspectos y problemas que alientan los productos autobiográficos sobre los cuáles se indaga y mucho en las colaboraciones que integran este libro, un excelente y completo recorrido por el territorio de la escritura del yo. Que, por otro lado, se engarza como un eslabón importante en esa cadena de estudios sobre el escribir autobiográfico y memorialista que en Brasil se ha ido soldando a lo largo de los años 90, con una mención destacada para la labor desempeñada y promovida por el GEDOMGE (Grupo de Estudos Docência, Memória e Gênero).

De igual modo que en otras latitudes, americanas y europeas, todo ello ha permitido fisgonear en los archivos personales y desempolvar no pocos «objetos autobiográficos», constituidos así en rico filón para una amplia gama de investigaciones planteadas desde atalayas bien diversas - literaria, histórica, antropológica, de género, educativa, psicológica, etc. - demostrando, de paso, que el único camino que puede hacer progresar los estudios sobre la cultura de lo escrito transita necesariamente por el abordaje interdisciplinar y por la conjugación de miradas. Ese planteamiento, evocado también en esta obra, conduce a una clara valorización de los escritos 
autobiográficos en la medida que éstos son piezas llenas de información, ya sea para la evocación de las costumbres y mentalidades de un determinado momento, ya sea para la configuración de las identidades, ya sea, en fin, por las referencias y apuntes que proporcionan de cara a cualquiera de las operaciones que tengan por objeto la reconstrucción del tiempo pasado.

Ana Chrystina Venancio Mignot abunda en estos pormenores basándose en el archivo personal de Armanda Alvaro Alberto, profesora y directora de la Escuela Regional de Meriti, amén de una persona muy empeñada en la reforma educativa y en la cuestión feminista en el Brasil de los años 20 y 30 del pasado siglo. La riqueza de sus papeles, conservados por la familia, le permite indagar en el recorrido vital de Armanda, y con ella en el movimiento de renovación pedagógica y en el debate político de su tiempo. Partiendo de eso, la autora, quien tiene muy en cuenta las tesis de Philippe Artières sobre los acervos personales, reconstruye la trayectoria de Armanda según se representa en cada uno de los documentos producidos o guardados por ella (fotografías, memorias escolares, recortes de prensa), concluyendo que "ao guardar velhos papéis em seu baú de memórias, Armanda procurou legar às futuras gerações sua crença na importância da educação, traduzida na intransigente defesa de uma escola de qualidade, sem discriminação econômica, racial, sexual, social. Editou sua vida como uma mulher à frente de seu tempo, na dianteira, na vanguarda. Ełernizou a imagem pioneira. Guardou para se guardar, para nos guardar do esquecimento" (p. 139).

Nótese, para seguir, que mujer, educación y cultura escrita son ejes principales que guían el conjunto de los trabajos. Sólo escapa parcialmente a esas coordenadas Jean Hébrard, cuya contribución explora la genealogía de las escrituras personales buscando la conexión entre los diarios y memorias de la época contemporánea y sus precedentes, más heterogéneos e híbridos, de la moderna. Recurre para ello al análisis etimológico de los vocablos asociados a dichas prácticas ("cahier", "carnet", "livre", "registre") y rastrea sus significados en los tres principales dominios de producción que dieron lugar a dichas escrituras: el administrativo (civil, religioso y judicial), el mercantil y el escolar, llegando a la conclusión de que uno de esos soportes, el cuaderno, tan ligado al mundo de la escuela, se convirtió en el siglo XIX en el "espaço gráfico mais banal e comum que pode existir" (p. 59).
Cavilar sobre el vocabulario empleado para designar los escritos personales y sobre la materialidad de los mismos conduce obligadamente a reflexionar sobre las condiciones que regulan dichas modalidades del escribir y las estrategias diseñadas en cada "objeto autobiográfico", ya que ello incide directamente en los horizontes de expectativas que cada persona se marca al escribir su vida o algún aspecto de la misma. Es esto algo que inspira la factura de este libro pues, como advierten las coordinadoras, su interés por los escritos personales es parte de una comprensión ampliada de la noción de documento según la ha formulado la historia cultural. Lo que quiere decir que, al enfrentarse a dichos textos, tanto importa el análisis de la forma material de las prácticas y de las maneras de resolver la relación con el instrumento escritura, como atender a las comunidades discursivas que interpretan dichos escritos y los inscriben en unas determinadas coordenadas espacio-temporales.

Así Zahidé Lupinacci Muzart estudia las propiedades de los diarios personales femeninos comparando determinados ejemplares del siglo XIX, sobre todo de viajeras extranjeras puesto que los de escritoras brasileñas son más difíciles de encontrar, con otros de finales del XX, "llevados" directamente en la Red. Ello le ha permitido constatar que los diarios en Internet han cedido en la tradicional introspección íntima, mientras que señalan más claramente la búsqueda de un interlocutor con el que compartir "seu olhar pelo mundo, por sua cidade, seu bairro, sua rua, numa volta à aldeia, ou seja, numa busca de solidariedade, de comunidade, de calor humano" (p. 188); por lo que, afirma, "o diário perdeu o segredo, a intimidade, mas continua a ser o registro do efêmero e do descontínuo tal como no século XIX, e, antes de mais nada, continua a ser uma maneira de viver" (p. 189). Al decir de Régine Robin/ Rivka A., una de las diaristas on line, el diario como testimonio de "a vida como um deambular urbano" (p. 188).

Pero en la medida que las escrituras del yo manifiestan la autoexploración del sujeto, leerlas y analizarlas "é buscar o processo de significação, o própio discurso numa prática significante", conforme sostiene Tânia Regina Oliveira Ramos, quien centra su indagación en las agendas de unas garotas de 13 a 17 años, esto es, auténticas piezas de formación. A través de ellas se percibe, señala la autora, cómo las niñas experimentan su crisis de identidad, su camino de afirmación y, en fin, la voluntad de mostrarse como personas completas, 
sin fisuras y sin brechas. $Y$ lo hacen mediante un discurso fragmentado y disperso a través del cual la vida se construye no como un acontecer continuo y progresivo, sino como el resultado de "juntar pedaços do cotidiano" (p. 197). De ahí una práctica de escritura que juega con las palabras y las imágenes, y que se materializa en un "libro de vida" formado por anotaciones de la más variada índole (preocupaciones personales, comentarios de películas o de canciones, declaraciones de amor, etc.), fotografías, recortes y testimonios varios, al punto de configurar un lenguaje muy simbólico en el que "querer dizer o indizivel parece ser um traço recorrente da escrita femenina" (p. 199).

Las cartas de adolescentes es el tema que desarrolla Maria Rosa Rodrigues Martins de Camargo, cuyo enfoque, muy atento a las ideas de Roger Chartier, toma en consideración las vinculaciones entre las prácticas y los soportes, y sus implicaciones en los procesos de apropiación y representación. Enunciados dichos planteamientos, la autora trata de aplicarlos a la correspondencia de dos adolescentes entre diciembre de 1990 y el mismo mes de 1996. Por un lado, estudia el objeto, es decir, la carta en sí misma, atendiendo a los aspectos materiales (tipología de los soportes y de los sobres), pero también a los lugares de la escritura y de la lectura, a la ceremonia epistolar; y por otro, reflexiona sobre el acto mismo del escribir ahondando en las funciones y en las estrategias del discurso epistolar, para concluir que las cartas, en la medida que espacios de escritura y de lectura, son igualmente lazos de unión entre las personas: "A carta é o veículo. A escrita, modos de ser. E a leitura, modos de ver" (p. 227).

Asimismo, la memoria y la identidad, según se comparecen en los escritos personales de autoría femenina, asoman como otros de los vectores que recorren las páginas de esta obra. Lilian Maria de Lacerda analiza con detalle la literatura autobiográfica de las escritoras brasileñas entre 1893 y 1998, cuyo itinerario está marcado "por descontinuidades entre os processos de escritura da memória femenina e os processos de sua divulgação, em função da censura social à mulher e das condições do própio comércio livreiro e editorial brasileiro" (p. 81). A partir de ahí se ocupa del binomio memoria/verdad y de la función que desempeña el olvido, ingrediente primordial en la configuración del recuerdo: "as fronteiras entre memória e esquecimiento são sutis" (p. 88); a la vez que disecciona la escritura memorialista como una actividad que tiene mucho de catártica pero que tampoco es enteramente ajena a la cultura del ocio, esto es, a las maneras en las que cada cual trata de "matar o tempo" (p. 96), según palabras de Maria Eugênia de Castro, una de las autoras citadas.

Ana Canen y Libânia Nacif Xavier lo plantean a partir de la obra Os meus romanos, alegrias e tristezas de uma educadora alemã no Brasil, de Ina Von Binzer, en la que se reúnen las cartas que esta preceptora escribió entre 1881 y 1883, esto es, en el período anterior a la abolición de la esclavitud. Si inicialmente la educadora mira y describe la realidad brasileña desde la pretendida superioridad europea, después irá cambiando su óptica para incidir más en la riqueza y diversidad cultural que tiene delante de sus ojos, de modo que "de uma atitude profundamente etnocêntrica manifestada nas primeiras cartas, a autora vai, pouco a pouco, compreendendo melhor o complexo funcionamento da sociedade escravista imperial, adaptando-se ao ethos brasileiro e efetivando uma nova síntese identitária" (p. 69). Ello supone la discusión del concepto mismo de memoria nacional como algo uniforme y monolítico, reemplazado por otro más adecuado para definir una realidad social señalada por la mezcla de identidades.

Ahí la memoria de la profesora sirve para analizar el choque y el mestizaje de culturas, mientras que en el caso de la escritora Sophia Lyra, su producción nos acerca a la situación de la mujer en el Brasil de los años 30. Es cierto, como expone Maria Arisnete Câmara de Morais, que la obra de Sophia y, en especial, su Vida íntima das moças de ontem (1980), "evidencia os mecanismos que enunciam e representam os papéis da mulher na sociedade, fazendo sua própia história" (p. 113); pero ni muchos menos se debe obviar que su modelo de «mulher que contesta, que batalha em busca de seu espaço» (p. 116), aunque fuera compartido por otras burguesas de la época, no tenía mucho que ver con las actitudes y los horizontes de vida de las mujeres de las clases populares, que, por supuesto, tampoco gozaron del mismo hábito de lectura seria y sistemática que Sophia Lyra tuvo desde niña.

La implicación de la lectura en la formación y en la configuración de la identidad personal la vemos igualmente en el diario de la joven Cecília de Assis Brasil, cuyo estudio aborda Maria Helena Camara Bastos. Nacida en Washington, hija de Joaquim Francisco de Assis Brasil, un personaje de 
renombre, abogado, político, diplomático y poeta, el diario de Cecilia de Assis, escrito entre 1916 y 1928, está repleto de anotaciones tocantes a sus lecturas preferidas, a los libros que sus padres no le permitían leer, a los lugares donde leía y a tantos otros aspectos cuyo tenor desvela que, efectivamente, "a leitura era central no universo cotidiano de Cecilia" (p. 149). Casi no podía ser de otra manera dados los más de 15.000 volúmenes que había en la biblioteca del padre.

El diario como la práctica más genuina de la escritura íntima es también el "objeto autobiográfico" sobre el que tratan los trabajos de Maria Teresa Santos Cunha y los ya referidos de Zahidé Lupinacci Muzart y Tânia Regina Oliveira Ramos. Si éstas los consideraron desde el hecho de la escritura y el orden del discurso, Maria Teresa Santos revisa los de varias profesoras para profundizar en las imbricaciones entre la memoria y la actividad educativa, que, junto con la autobiografía, forman el trípode conceptual que sustenta Refúgios do eu. Pero no lo hace por lo que tengan de escritos íntimos, sino atendiendo a las observaciones y reflexiones sobre la vida pública, lo que, dicho sea de paso, era también un rasgo bastante común en los objetos-memoria de la época moderna. Aquí esa mirada está ligada a los anhelos profesionales de dos jóvenes catarineses que pergeñaron sus notas entre 1964 y 1974, justo cuando se estaban preparando para ser maestras, por lo que sus diarios sirven para mostrar cómo vivieron y representaron su ingreso en la vida profesional, al punto de componer "um mosaico que integra as maneiras de se perceber no mundo" (p. 178).

A la postre, las distintas colaboraciones exploran diferentes prácticas y modalidades de la escritura del yo, e insisten en el valor del testimonio individual. Al hacerlo, Refúgios do eu deja ver sus conexiones con la historiografía que más ha propiciado el retorno del sujeto y lleva dicho enfoque a un campo, el de la historia de la educación, donde, en palabras de Antonio Viñao Frago, responsable del prólogo, "lo habitual, hasta fechas no muy lejanas, era tanto el predominio de los discursos esencialistas y normativistas, como el de una historia abstracta e irreal de unas ideas 0 , como se decía, de un pensamiento pedagógico, desvinculado de sus contextos de producción y recepción, al que se recurría como fondo de citas de autoridad, cuando no de recetas, para justificar o evaluar determinadas propuestas o medidas educativas" (p. 9).

Rescatado el sujeto como protagonista del devenir histórico y su palabra como testimonio elocuente, cada una de las escrituras traza, de facto, un camino que siempre se mueve entre dos estaciones: la del individuo y la del colectivo, la del sujeto personal y la del sujeto social. Las autobiografías exploran la intimidad y lo específico del ser humano; pero a la vez iluminan sobre las concretas coordenadas de espacio y tiempo en las que se sitúan, según deja ver el aprovechamiento que de ellas se hace y se propone en Refúgios do eu. El libro contiene un buen ramillete de incursiones en vidas anónimas e incluso corrientes, casi como si se tratara de un ladrón en casa ajena, al modo que Philippe Artiéres ha descrito su "intromisión" en las existencias de una decena de criminales de finales del siglo XIX y principios del $X X{ }^{\prime}$ 'Siviéndose de ese material, se desmenuzan muchos ingredientes de la "educación de los sentimientos", es decir, aquélla encargada de transmitir lo que se esperaba de la mujer, canalizada a través de la familia, de los confesores y de los educadores, tan determinante en la instrucción y en la formación lectora de las mujeres, sobre todo en el siglo XIX y en la primera mitad del $X X X ;^{2}$ lo mismo que se detiene en múltiples consideraciones sobre los avatares de la enseñanza en el Brasil de ambas centurias, singularmente conforme los vieron y experimentaron las mujeres protagonistas de estas "vidas de papel". ${ }^{3}$

Sus páginas, comprometidas y rigurosas, demuestran que no hay escrito insignificante en la selva de los textos, pues, como afirma Ana Chrystina Venancio Mignot, cualquiera de los personales "fornecem informações sobre o cotidiano, formas de ver o mundo através de fatos comuns da experiência humana, hábitos, costumes. Contêm pequeninas coisas com grande poder lembrança" (p. 124). Representan fragmentos de memoria y, en consecuencia, según plantea Margarida de Souza Neves en el epílogo, incluso deben ser explicados como 'metáforas expresivas' que conectan con los clásicos artes de la memoria, de tal modo que los autores de la moderna escritura autobiográfica "não deixam de assumir uma função análoga à do mnemom da mitologia grega, a de ser aquele que lembra. São eles que, como Sísifos ou como Penélopes, assumem modernamente a tarefa interminável de fazer da memória a arte de dizer a vida" (p. 236).

Por ello que, como sostuviera Giuseppe Tommasi Di Lampedusa en sus Ricordi d'ínfanzia (1961), "quello di tenere un diario o di scrivere a una certa età le proprie memorie dovrebbe essere un dovere "imposto dallo Stato", agregando que "il materiale che si sarebbe accumulato dopo tre o 
quattro generazioni avrebbe un valore inestimabile" ", para afirmar que "non esistono memorie, per quanto scritte da personaggi insignificanti, che non racchiudano valori sociale e pittoreschi di prim'ordine". Salvo la "certa età" como requisito para escribir un diario, que dejaría fuera tantas cartas y cuadernos de adolescentes y jóvenes, lo demás suena rotundo y enteramente cierto. Su mejor prueba, Refúgios do eu.

'Le livre des vies coupables. Autobiographies de criminels (1896-1909), textes édités et présentés par Philippe Artières,
Paris, Albin Michel, 2001, p. 7.

${ }^{2}$ Maria Teresa Santos Cunha, Armadilhas da sedução. Os romances de M. Delly, Belo Horizonte, Autêntica editora, 1999.

${ }^{3}$ Tomo el término de un reciente libro sobre los archivos y las escrituras autobiográficas cuya lectura puede completar la de la obra aquí comentada. Me refiero a Vite di carta, a cura di Quinto Antonelli y Anna luso, Napoli, L'ancora, 2000.

\section{Pedagogias do corpo ou a constituição de bons-moços e boas-moças.}

\author{
Corpo, Identidade e bom-mocis- \\ mo: cotidiano de uma adolescên- \\ cia bem-comportada.
}

FRAGA, Alex. B.

Belo Horizonte: Autêntica, 2000.164p.

O livro de Alex Fraga, produto de sua dissertação de mestrado realizada na Universidade Federal do Rio Grande do Sul, faz-nos enveredar pelos meandros de uma adolescência bem-comportada na qual jovens de "boa cabeça" estão em estreita sintonia com os preceitos da escola, da família e da religião católica, diferentemente daquilo que a mídia propala como característico da juventude atual: a rebeldia, a revolta e o afastamento paulatino dos valores da família, o descaso para com a escola e um questionamento das doutrinas religiosas.

A pesquisa, feita numa escola municipal de Cachoeirinha, na região metropolitana de Porto Alegre, tomou como sujeitos alunos e alunas de uma $8^{a}$ série do Ensino Fundamental e analisou principalmente os comportamentos desses/as jovens durante as aulas de Educação Física - nas quais eles não eram separados por sexo. $\mathrm{O}$ autor buscou tornar visíveis regras, modos de se comportar, que representavam jeitos de ser voltados para aquilo que tradicionalmente reconhecemos como os "bons costumes". A análise incidiu na forma como a sujeição às regras que conformam os bons costumes, incitadas pela forte influência do aparato escolar, e em consonância com o desejo das famílias, marcam os corpos dos sujeitos/alunos e alunas, a fim de que se tornem "bonsmoços" ou "boas-moças".

Procurando dar forma e compreensão às vozes dos sujeitos, articulando-as a sua própria voz, o autor apropriou-se dos Estudos Culturais, entrecruzando-os com os Estudos Feministas que enfocam o corpo, o gênero, a sexualidade e a educação. Apropriou-se também dos conceitos de discurso e sujeito de Foucault, procurando dar sentido às práticas que se produzem no ambiente escolar, mesmo que não sejam próprias unicamente desse ambiente, porque fazem parte da complexa trama que produz relações de poder e confere lugares distintos aos sujeitos. É considerável, então, o esforço do autor para não escorregar em análises de cunho psicologizante como o faz grande parte da produção teórica desse campo.

Localizando geograficamente os sujeitos $e$ os espaços de sua pesquisa, no capítulo "Sujeitos e Lugares", Fraga não só nos leva através da cartografia de Cachoeirinha, mas também chama a atenção para o fato de que a localização geográfica não é suficiente para entender como os sujeitos constroem o que, a partir de Certeau, ele denomina "sentimento de cidade". A partir disso, Fraga analisa as maneiras como os/as alunos/as cons- 
truíam um lugar particular que estava inserido num espaço urbano mais amplo. Ou seja, o autor interessou-se pelo mapa da cidade que era desenhado a partir dos/as alunos/as pesquisados/as A movimentação dos alunos e das alunas por diferentes lugares conferia sentidos particulares a esses locais. Portanto, ao cruzarem diferentes fronteiras territoriais no município, teciam suas imagens do território a partir de seus valores e crenças.

O sentimento de cidade é uma construção que se desenvolve a partir de múltiplos fatores, como as histórias e as memórias contadas, que promovem imagens e que possibilitam às pessoas se conectarem, ou não, umas as outras. Para os/ as alunos/as, os diferentes lugares por onde circulavam produziam uma visibilidade de diferentes modos de vida, nem sempre compatíveis com a moral e os bons costumes praticados por eles/as próprios/as.

A maneira como iam sendo produzidos os valores morais incorporados pelos/as jovens estava em estreita consonância com os relatos de uma escritora local, Isabel Mombach, dos quais o pesquisador se apropria e que evidenciam um intenso poder da igreja na regulação dos modos de vida daquela população. Outras instituições, como a escola por exemplo, vão conformando-se a esse poder, que dita as normas morais e as regras de bons costumes. Evidentemente essas normas não são absorvidas de forma consensual por todos os/ as moradores/as da localidade.

No caso dos/as moradores/as de Cachoeirinha, há construções identitárias diferenciadas entre aqueles/as que habitam o lado direito da avenida central da cidade e aqueles/as que habitam seu lado esquerdo. Há inclusive rivalidades que se evidenciam entre esses dois lados. Durante o deslocamento da professora de educação física juntamente com os/as alunos/as a um complexo esportivo onde seria ministrada a aula, as diferenças de posições e de submetimento aos discursos iam se desenhando de forma mais nítida, ensejando sentidos diferenciados para cada lugar.

A turma de $8^{a}$ série possuía algumas peculiaridades, como o fato de a maioria de seus componentes estudarem há algum tempo juntos num mesmo grupo e serem caracterizados pela maioria dos/as professores/as como uma "boa turma" ou, como alguns/mas professores/as se referiam a eles/as, eram "uns amores". A constituição desses sujeitos também está suscetível aos rituais de disciplinamento organizados pela escola, como por exemplo no conselho de classe, onde são su- geridos os comportamentos ideais para os alunos e alunas no bimestre seguinte.

Assim como vários estudos têm demonstrado, e à luz de Foucault, é possível distinguir a escola como espaço de disciplinamento dos corpos e das mentes humanas. Com um poder de sedução tenaz, a instituição escolar promove a culpa e incita o castigo no caso de qualquer resistência a suas regras. No caso da adolescência, torna-se necessário compreendê-la melhor, a fim de entender os efeitos do discurso da escola e da família sobre ela.

Mas como entender melhor a adolescência sem enquadrá-la em recortes temporais? No capítulo "O tempo 'tatuado' no corpo", Fraga faz uma busca na produção teórica sobre o tema, tratando das questões pertinentes à adolescência e trazendo de antemão uma de suas mais difundidas descrições: a de uma "etapa" da existência humana marcada pela instabilidade das emoções e por comportamentos impulsivos. Essas formulações, já suficientemente criticadas pela produção teórica, demarcam a adolescência não só por sua temporalidade, mas igualmente pela negatividade desse tempo.

No entanto, outras tentativas mais recentes de caracterização da adolescência, que se baseiam na noção de dependência/independência da família, também parecem ser insuficientes, porque, respaldando-se em compreensões meramente biologicistas, negam a inserção cultural que os conceitos de dependência ou independência engendram. Na verdade, essa compreensão não avança em relação a "etapização" imposta pelas ciências dominantes à compreensão da vida humana em sociedade.

A educação, e conseqüentemente a escola, são fortemente influenciadas pelos discursos da Psicologia evolutiva e da Biologia, que instituem os regimes de verdade quanto aos comportamentos normais, próprios aos adolescentes. Há a crença, inclusive, de que a propalada "crise da adolescência" é, ao mesmo tempo, a constante dessa fase e seu tempo de passagem, exigindo dos/as professores/as, por exemplo, muita paciência e abnegação para que num dado momento tudo chegue a um bom final.

A natureza biológica das explicações ditas "científicas" sobre a adolescência, por seu viés psicologizante, vai estruturando as subjetividades e desenhando o padrão de normalidade para os comportamentos, de forma que qualquer violação pode provocar atitudes fora-de-controle, o 
que justifica a necessidade de uma constante vigilância sobre os/as jovens, assim como faz a instituição escolar.

Qualquer transgressão juvenil aparece nos enunciados como uma ameaça à vida em sociedade e é apresentada como produto do desmantelamento dos valores da família. Os pais também aparecem em inúmeras pesquisas como os responsáveis pelos comportamentos incontroláveis dos/as filhos/as adolescentes. No entanto, e como ressalta Fraga, não só a família, mas também a escola é responsabilizada pela conturbação dessa fase da vida. Uma alternativa é evitar o contato com as ruas para conseguir manter uma atmosfera de bons princípios. O filme Kids tem sido utilizado como um exemplo da "demonização" dos corpos adolescentes, demonstrando o discurso da adolescência perdida dos anos 90.

Diante de atos de demonização - uso de drogas, sexo fácil e agressividade - a escola pretende garantir a correção dos corpos desajustados através dos rituais de confinamento e purificação. Na escola aprende-se a controlar não só os próprios corpos, mas também os corpos dos outros.

O pesquisador observou que boa parte dos/ as jovens da escola pesquisada apresentava um comportamento coerente com aquilo que poderia ser denominado uma adolescência endeusada - mais ajustada à mecânica social e conduzida por valores tradicionais como a família, a igreja e a escola - em contraposição à disseminada demonização. Uma moralidade cristã de orientação católica perpassava o modo de ser de alguns/ mas desses/as jovens, que afirmavam ter Deus dentro de si.

A estreita ligação de boa parte dos/as adolescentes com movimentos vinculados à igreja católica era o fio condutor das relações que estabeleciam dentro e fora da escola. De diferentes maneiras, meninos e meninas iam concretizando formas de controle ou de "exorcismos" uns/mas sobre os/as outros/as, com o consentimento das famílias em estreita relação com aquilo que Foucault denominou "tecnologias do Eu". A busca da pureza, da felicidade, a assepsia do espírito, tornava-se um sonho a ser alcançado. Entretanto, o texto parece ocultar algumas contradições decorrentes da submissão aos valores religiosos. Em algumas falas dos sujeitos está presente a negação desses valores, o que é sabidamente motivo de desavenças e conflitos entre adolescentes. Assim como a escola oculta as diferenças, o texto permite somente esparsos momentos em que essas diferenças debatem entre si, do mesmo modo como a orientação da escola parece ser consensual em relação às normas de controle.

Nos processos de construção das identidades adolescentes, o autor enfatiza que elas não se constituem a partir de uma referência binária do tipo endeusado/endemoniado. Há entrecruzamentos que não permitem demarcar fronteiras muito nítidas entre um e outro modo de ser. A escola, porém, insiste em atuar diretamente nos processos de recristianização, através da elevação e do reforço de condutas condizentes com o "tenho Deus dentro de mim", acentuando comportamentos positivos e banindo aqueles que ela enquadra como negativos.

Aqueles/as que se salvam das garras da promiscuidade, do sexo desmedido, do uso de drogas, da violência, da agressividade, e aceitam os preceitos dos bons costumes vão formando a legião de bons-moços e boas-moças. Essas duas classificações adquirem algum sentido a partir de uma série de categorias, como classe social, gênero, sexualidade, etnia, nacionalidade, distinção etária.

Quanto às distinções de gênero, Fraga toma como referências Scott e Connell e, a partir destes, destaca que é nos corpos que as práticas sociais generificadas atuam, especialmente aquelas que se constituem na escola. A Biologia ainda se mantém como a ciência que promove as distinções entre homens e mulheres. Nesse caso, as práticas sociais estariam biologicamente determinadas.

Nessa perspectiva, as meninas precisam ter um cuidado especial com seus corpos, objetivando a futura maternidade, necessariamente associada ao recato e à decência necessários a uma boa mãe de família. Aos meninos que desejam ser bons-moços, é exigida uma masculinidade baseada em traços tradicionais: é preciso ter um corpo ativo e desbravador.

De acordo com Scott (1995, p. 93), "homem e mulher são, ao mesmo tempo, categorias vazias e transbordantes. Vazias, porque não têm nenhum significado último, transcendente. Transbordantes, porque mesmo quando parecem estar fixadas, ainda contêm dentro delas definições alternativas, negadas ou suprimidas". O autor identifica inúmeros momentos, em sua estada junto aos meninos e meninas de sua pesquisa, que ratificam esta afirmação. Ou seja, em algumas passagens, as meninas julgam comportamentos de colegas do sexo masculino a partir de valores morais eminentemente masculinos. Igualmente, entre as 
meninas, há julgamentos morais acerca do que é feio ou permitido para elas, mas tanto os meninos quanto as meninas enunciam dúvidas, interrogações, e deslizam constantemente em campos e papéis nos quais a masculinidade e a femininidade estão em construção.

Esses achados são mais bem compreendidos quando tomamos o capítulo "Corpo em Discurso", no qual o autor chama a atenção para o poder de penetração dos discursos que vão sendo inscritos nos corpos dos sujeitos de forma imperceptível. Os discursos possuem um duplo efeito: ao darem um sentido à normalidade, apresentam o anormal. Os corpos são artefatos produzidos por tecnologias que marcam as diferentes épocas. Os limites e as possibilidades do corpo são, então, determinados por pedagogias e poderes reguladores que se apresentam de maneira sutil e de diferentes formas no cotidiano dos sujeitos.

Historicamente é perceptível que a narrativa cristã sobre a bondade e a maldade está vinculada à oposição entre corpo e alma. O corpo, impuro, precisa ser transformado, controlado, disciplinado para atingir a perfeição ou a imagem e semelhança de Deus. A negação do próprio corpo constitui, dessa forma, a elevação da alma cristã. A integridade da alma depende diretamente da contenção dos gestos, dos movimentos, da expressividade.

Os/as adolescentes observados davam forma ao discurso do bom-mocismo: a discrição com que se portavam, a atenção e a concentração nas aulas, a sujeição às normas da escola. Até mesmo as roupas que usavam, que pouco distinguiam os meninos das meninas, destacavam as cores sóbrias, os modelos largos, enfatizando que a exposição do corpo não era uma preocupação desses/as jovens.

Nas aulas de educação física, mesmo naquelas atividades pouco prazerosas, como o futsal para algumas meninas, e nos movimentos gimnodesportivos para os meninos, havia uma sujeição com discretas resistências dos/as adolescentes. Sabidamente, há fortes resistências culturais à dança pelo sexo masculino, assim como as meninas rejeitam os esportes mais agressivos. A turma observada apresentava somente discretas resistências a propostas como essas. Parece que a professora de educação física exercia um forte poder de sedução sobre a turma, convencendo-a em vários momentos a se "integrar" na atividade por ela proposta. Aparentando um diálogo constante com os/as alunos/as, determinava aquilo que era para ser realizado ou não. No esforço de não desautorizar uma professora "legal", "amiga", num meio onde há tantos supostos "inimigos etários", sabemos que muitos/as adolescentes acabam aceitando propostas nem sempre consoantes com aquilo em que acreditam, e até mesmo se submetendo a alguns "vexames" ou micos.

Através dos relatos é possível identificar que havia no grupo sexualidades em questão. Porém, esse é um tema constantemente silenciado pela escola e pela família, que jogam uma para outra a responsabilidade da formação de seus/as filhos/as ou alunos/as. Quando necessário, a escola, como trata do conhecimento, invoca aqueles que seguem o estatuto científico para falar do assunto, ou seja, médicos e psicólogos, como os especialistas na matéria, o que impede outras formas de se compreender esse tema, estreitando o olhar.

Para finalizar, cabe destacar que a conformação ao bom-mocismo entre os/as jovens pesquisados/as não era um comportamento homogêneo. No entanto, mesmo para aqueles não tão bons moços ou moças, as regalias conquistadas pela turma eram vantajosas, o que nos leva a pensar que alguns eram bons-moços de crença, e outros, de interesse. Uma dúvida que permanece após a leitura do texto diz respeito àquilo que vem sendo denominado de conformação ao discurso. Há uma conformação incondicional ao discurso da escola e da família? Ou um certo adultocentrismo não nos permite ver que arranjos são elaborados por muitos/as adolescentes para que uma "aparente" conformação torne mais suportável a passagem pelo ambiente escolar, tornando também menos tensa a vida no meio familiar, ambos demarcados pela "adultês", que não consegue concebêlos para além de "meramente jovens?"

DÉBORAH THOMÉ SAYÃO 


\section{Cenas da vida amorosa brasileira na modernidade tardia}

\author{
Reinvenções do Vínculo Amoroso
}

MATOS, Marlise.

Belo Horizonte: UFMG/IUPERG, 2000. 332p.

As relações de parentesco sempre foram, para as ciências sociais, um tema fecundo para se pensar a sociedade, de forma a poder compreendê-la em seus diferentes níveis institucionais. A família, território geográfico e rede social onde se mantêm as relações mais próximas, é um dos aspectos fundantes da sociedade por se constituir como uma estrutura dentro de muitos grupos sociais. Na realidade, a família é, depois da revolução burguesa e industrial, a "cápsula mãe" (atualmente já bastante terceirizada) do cidadão livre. Através das transformações da família moderna, as relações de parentesco vêm configurando novas redes amorosas junto com as sociais e as políticas. É nesse contexto que a ideologia do amor conjugal desempenha um papel importante no que concerne à estabilização e/ou transgressão de regras sociais na mudança da sociedade. A família, ou melhor, a relação conjugal, é um estado social no qual podemos renovar projetos individuais e ampliar o campo de possibilidades.

O belo trabalho desenvolvido por Marlise Matos em Reinvenções do vínculo amoroso - cultura e identidade de gênero na modernidade tardia vem nos mostrar o surgimento de outras identidades de gêneros e de vínculos amorosos na modernidade. O livro está dividido em seis capítulos, nos quais a autora traça uma longa reflexão entre as macro teorias sociológicas, as psicanalíticas e os estudos de casos realizados por terceiros (nesse último aspecto, HEILBORN, 1992, 1996 parece ser a grande mentora intelectual da autora no que diz respeito à conjugalidade homossexual na cidade do Rio de Janeiro).

A pesquisa se baseou nos contatos realizados com 11 casais, hetero ou homossexuais, que mantinham relações estáveis, entre 3 e 15 anos (capítulo IV, p. 164). Exclusivamente membros da classe média carioca, o grupo de informantes foi constituído por profissionais de nível técnico espe- cializado e por profissionais liberais de idades entre 22 e 54 anos. O trabalho de campo foi realizado na aplicação de survey. Os locais das entrevistas variaram entre os lares, os bares e o trabalho.

O primeiro capítulo é dedicado à análise do gênero em suas dimensões culturais, tanto objetiva quanto subjetivamente. Partindo de Simmel, sobre a questão da experiência da modernidade, da dominância da cultura objetiva sobre a cultura subjetiva (p. 36), Marlise Matos reafirma que a sexualidade é uma forma de hierarquizar a sociedade e portanto uma forma de estabelecer relações específicas entre homens e mulheres. Nesse sentido, ao estabelecer a dominação do masculino sobre o feminino, na sociedade burguesa, temos a predominância da "cultura fálica do gênero" (p. 40), na qual as relações patriarcais permeiam as múltiplas dimensões da sociedade - sexual, social, cultural, econômica e política. Dados os aspectos patriarcais dominantes na relação conjugal que a sociedade ocidental adotou como padrão e portanto uma "normatização compulsória da heterossexualidade" (masculina), assistimos em nossos dias ao surgimento de novas formas de estabilidade conjugal. Não só as relações homoeróticas tomaram maior visibilidade social e política, reivindicando direitos cívicos, como o heteroerotismo buscou outras combinações de relações conjugais (casamentos não formais, moradias separadas, mãe provedora do lar etc).

Atualmente, se o multiculturalismo entrou definitivamente na pauta das discussões sobre pósmodernidade, o tema do multissexualismo inova as reflexões sobre o que a autora denominou "culturas alternativas de gênero", ou ainda "experiências alternativas de conjugalidade". Indo além dos estereótipos dos modelos exclusivamente hetero ou homossexuais de casais, a autora aborda outras formas de relações amorosas, e conseqüentemente outras identidades de gênero, como os bissexuais, os travestis e os "trans". De fato, Marlise opta por analisar uma sexualidade heterogênea nos aspectos em que ela se apresenta em nossos dias.

O segundo capítulo é dedicado à contribuição teórica entre sociologia e psicanálise no que concerne às identidades de gênero. Tomando o interacionismo simbólico como referência teórica, Matos perpassa suas reflexões entre o plano 
individual e o coletivo. Uma vez que "a conduta humana é social e não pode ser explicada meramente como resultado de esforços individuais, e que, portanto, a tarefa do interacionismo simbólico foi tentar dar conta da formação e variedades das condutas humanas" (p. 76), Matos analisa as identidades de gênero, enfocando tanto a pessoal e a subjetiva quanto a coletiva e a social.

Posteriormente, a autora passa por metadoutrinas como as de Freud e Marx, pela Escola de Frankfurt e chega à teoria dos papéis de Parsons, com o objetivo de discutir a divisão sexual do trabalho no interior da família e como essa divisão influencia na formação de gêneros coletivos, sejam eles pessoais, sexuais, afetivos ou emocionais. Finalmente, o último item do segundo capítulo aborda a estética e a ética na identidade de gênero. Performance e moral constituem uma dinâmica específica dos gêneros, dando à relação conjugal uma dimensão politicamente transgressora e ao mesmo tempo estabilizadora. Na realidade, Matos acredita que a ética e a estética são aspectos culturais e podem ser vistas como fronteiras (ou coexistência de vários gêneros) no tempo e no espaço. Segundo ela, "são formas sócio-culturais criativas, esteticamente reflexivas e eticamente orientadas de interação e reinvenção do vínculo amoroso" (p. 120).

"As parcerias" são recortadas por seis cenas e "montadas" (p. 186-205) para demonstrar as novas "estabilidades conjugais" nas experiências alternativas amorosas, homo ou heteroeróticas. A crise de certos paradigmas nos tempos atuais levou necessariamente a uma revisão das relações conjugais, e a família moderna se viu obrigada a se reorganizar e a flexibilizar os modelos tradicionais dos papéis masculinos e femininos. Essa mudança de papéis e o surgimento (maior visibilidade) de outras sexualidades, essas últimas não ancoradas no modelo heterossexual tradicional, permitiram que novos "códigos" e estéticas de relação conjugal pudessem aparecer.

No capítulo seguinte, Matos discute a construção de identidades de gênero segundo a visão psicanalítica. ${ }^{1}$ Caracterizando a personalidade moderna a fim de distinguir os conceitos de subjetividade e identidade, o objetivo é se "libertar" teoricamente das amarras das discussões estruturalistas da psicanálise, não raro incisivas e "fundamentalistas" (a autora se refere ao aspecto "fundacionista" dessas teorias). Essas meta-teorias, nas análises do comportamento sexual humano, "pensa[m] a subjetividade como um status ontológico universal" (p. 209). De forma oposta, a intenção da autora é introduzir o conceito de transperformance, não apenas para pensar as novas identidades (hetero-)sexuais mas igualmente para confrontar outros estilos de gênero como gays, lésbicas, bissexuais, travestis. Mesmo que a autora analise as múltiplas e diversas formas de sexualidade e culturas de gênero, ela procura demonstrar formas de estabilidade conjugal a partir de comportamentos "marginais". ${ }^{2}$ Principalmente no que diz respeito aos homossexuais, o movimento de libertação do modelo hetero-fálico de sexualidade é visto, num primeiro momento, como transgressor e renovador. Sincronicamente, existe um esforço (político e científico) em encontrar na sexualidade de gays e lésbicas uma situação de normatização como "prova" de idoneidade social.

De qualquer maneira, nas diversas e variadas identidades de gênero produzidas atualmente, e ao contrário das visões médica e psicanalítica tradicionais, Matos reconhece que as novas formas de sexualidade não são desvios ou distúrbios. Para ela, a multissexualidade se apresenta como novos campos de possibilidades na afirmação de diferentes "estilos de vida".

Por fim, Matos aborda a dimensão espaçotemporal do gênero e da sexualidade, e por extensão das relações conjugais. Assim como Butler (1993), a pesquisadora acredita que o gênero possa se transformar num espaço de renovação de identidades capaz de contestar a hegemonia do modelo hetero-fálico da sexualidade. Se novos espaços para novas relações estão em jogo, o tempo igualmente toma um aspecto particular. Já não podemos pensar o tempo das relações conjugais como fatos ordenados, fixados em rituais determinados. A dimensão espaço-temporal se transforma num "lugar" de fronteira onde os diferentes corpos e as mais diversas identidades e culturas de gênero se cruzam, se confrontam e se relacionam, produzindo novas configurações e sentidos às relações amorosas.

Sem dúvida, o trabalho de Marlise Matos é intelectualmente instigante. Ela conseguiu, com competência, reunir teorias da sociologia e da psicanálise para refletir as novas configurações amorosas na modernidade brasileira. Trabalhando com autores clássicos e pós-modernos de ambas as áreas, a autora procura demonstrar como a transgressão sexual se tornou um campo de inovação e renovação das identidades e das culturas de gênero.

A partir dos movimentos das minorias sociais nos anos 60 e 70, gays e lésbicas (entre outros) passaram da imagem de desviantes, com algum distúrbio psicológico, para um grupo de pessoas 
normais, livres e cidadãs. Antes da Aids, principalmente os gays incorporaram a imagem de "forasteiros", verdadeiros cowboys da modernidade, sem regras, sem lei ou territórios fixos nos quais se pudesse controlá-los. No entanto, depois da Aids, social e politicamente os fatos tomam outra direção. Vinculados a uma necessidade de maior garantia civil, a Aids veio impulsionar, ao menos nos debates políticos, gays e lésbicas a lutar pela normatização de suas relações conjugais. Atualmente, as pautas de reivindicação são a parceria civil e também a adoção e a criação de filhos. Para tanto, é preciso que os homossexuais "provem" que são passíveis de assimilar certas regras sociais como a redução e a fixação do/a parceiro/ a sexual. Mais importante do que isso é a durabilidade das relações. Esse era o modelo heterossexual tradicional. Enfim, a identidade sexual e de gênero de gays e lésbicas, que antes era uma transgressão, uma atitude contestatória, tornouse uma modalidade de relação normal e estável.

No que concerne aos casais heterossexuais, houve um movimento inverso. Durante muito tempo, presos ao rígido modelo fálico-patriarcal da classe burguesa, o movimento feminista trouxe, ainda que de forma um tanto eclipsada, a consciência "masculinista". Não só as mulheres heterossexuais reivindicam a mudança de papéis e comportamentos para ambos os sexos, como também obrigam os homens a se reposicionar com relação à família e ao gênero feminino. Mas as mulheres também mudaram ao liberar os homens da fidelidade eterna, entrando no mercado de trabalho, tornando-se provedoras dos lares e não se fixando a um só parceiro $^{3}$ (mesmo que a fidelidade seja ainda uma característica bastante feminina).

De fato, a grande renovação dos vínculos amorosos está, na modernidade tardia, nos casais heterossexuais que procuram outras formas de relações como moradias separadas, parceiros/as extra-conjugais, mulheres como chefes de família etc. Apesar da transgressão e da renovação que uma relação homossexual pode trazer às pessoas envolvidas, a conjugação amorosa homoerótica parece estar "condenada" a reproduzir o modelo heterossexual de relação estável.

' Essa discussão, na realidade, se inicia no segundo capítulo do livro, quando a autora se propõe a fazer uma reflexão teórica entre a psicanálise e a sociologia. ${ }^{2}$ Marlise Matos possui discussões interessantes acerca das relações amorosas na modernidade, sobretudo no que concerne às novas identidades de gênero. Porém, a autora está à procura de características estabilizadoras das relações conjugais nos tempos ałuais.

${ }^{3}$ Esse aspecto implica que os parceiros extra-conjugais, tanto das mulheres quanto dos homens heterossexuais, não se definam pelo sexo oposto.

\section{Ciudadania y Derechos Economicos: la Importancia de la Tierra Para Las Mujeres Latinoamericanas.}

Género, propiedad y empoderamiento: tierra, Estado y mercado en América Latina

DEERE, Carmem Dlana y LEON, Magdalena.

Bogota: Tercer Mundo y Universidad Nacional, 2000. 501p'
El libro de Carmen Diana Deere y Magdalena León presenta los resultados de una investigación comparativa sobre los derechos de las mujeres rurales a la tierra en 12 países de América Latina y analiza fundamentalmente dos períodos: los procesos de reforma agraria de los años 60 y 70's y la fase que las autoras denominan las contrareformas neoliberales para referir a la nueva etapa de reestructuración del sector agrícola que, entre otras cosas, implicó la promulgación de nuevos marcos legales en diversos Estados, que tuvieron como denominador común la privatización y/o individualización de los derechos a la tierra.

ANO $9 \mathbf{3} \mathbf{1} \mathbf{6}^{2 \circ}$ SEMESTRE 2001 
A través del análisis de estos dos procesos las autoras discuten una diversidad de temas que alimentan el debate de varios campos: los estudios agrarios, los estudios sobre género y desarrollo, los desafíos del feminismo en América Latina. En este comentario me quiero concentrar en los aportes que esta empresa comparativa hace a la reflexión sobre la construcción de la ciudadanía de las mujeres en general, y de las mujeres rurales en particular y lo haré resaltando tres puntos:

1 La investigación ofrece un análisis de las vicisitudes del largo y a veces sinuoso proceso de implementación de políticas públicas de género en nuestros Estados, demostrando los mecanismos legales, institucionales, culturales y estructurales que acaban por excluir a las mujeres campesinas de la propiedad y control sobre la tierra. Se trata de un estudio pormenorizado de los diferentes actores involucrados en estos procesos político-institucionales, de los tiempos y los contextos económicos y sociales en que se desenvuelven dichos actores y de los marcos normativos que los rigen. Esto con el fin de demostrar cómo el engranaje de cada uno de estos temas devela la forma en que opera lo que las autoras denominan la brecha entre igualdad formal e igualdad real, que también podríamos denominar igualdad de derechos y desigualdad de oportunidades para las mujeres campesinas en el neoliberalismo.

1. En segundo lugar, un tema central en el libro es la relevancia de la propiedad para pensar en procesos de empoderamiento de las mujeres, es decir la relación entre bienes materiales y poder de negociación, entre derechos económicos y sociales y la necesidad del reconocimiento de la diferencia. Las autoras reconstruyen para el caso de la tierra la forma en que se presenta esta imbricación entre redistribución y reconocimiento en la construcción de la ciudadanía de las mujeres.

2. En tercer lugar, quisiera resaltar en este comentario la forma en que es tratada en el libro la articulación entre género y etnicidad como uno de los temas de mayor relevancia para el caso ecuatoriano. En este punto, las autoras presentan un interesante análisis de las tensiones entre feminismo y relativismo cultural, entre derechos colectivos y derechos individuales, entre el respecto a usos y costumbres y procesos de exclusión de las mujeres. En definitiva entre concepciones estáticas de la cultura y perspectivas que apuntan a recrearla o, como lo señala una indígena mexicana en el libro, visiones que permitan pensar la costumbre desde una perspectiva que las incluya.

Por ultimo quiero presentar algunos aspectos generales que me parecen necesarios señalarlos como aportes para la investigación de género en América Latina.

Respecto a la brecha entre igualdad formal e igualdad real, ésta aparece como una característica fundamental de la forma como se construye la ciudadanía de las mujeres y de las mujeres rurales en particular. Me parece que el estudio comparativo de cómo este proceso ocurre de manera distinta y similar a la vez en 12 países de América Latina nos ayuda a complejizar los procesos de construcción de la ciudadanía de las mujeres. Nos ubica por un lado, todos los actores que están inmersos en esta construcción: el Estado, con sus leyes y sus funcionarios, el movimiento de mujeres y sus coyunturas, la agenda internacional feminista, las organizaciones campesinas. Y por otro lado, analiza cómo los valores, prácticas y en general la cultura de género que permea instituciones y actores presenta obstáculos para que esta construcción de la ciudadanía de las mujeres sea un proceso lineal, en consonancia con los avances en el terreno de la igualdad formal.

Encontramos en el libro un análisis detallado no solo de los efectos que ha tenido las políticas neoliberales en el agro sobre la propiedad de la tierra para las mujeres sino también del complejo 
proceso institucional y cultural que implica la aplicación de políticas publicas de género en el contexto neoliberal. El estudio está lleno de ejemplos de cómo desde México a Chile y Brasil, a pesar de los logros legales, alcanzados recién en la década de los noventa en América Latina, de la existencia de determinadas reglamentaciones y hasta de instituciones encargadas de su aplicación, la implementación de estas políiticas se topa con la reacción negativa de los propios funcionarios, de un "habitus" que puede implicar desconocimiento de la ley, falta de voluntad para aplicarla, ignorancia frente a la problemática de género, pero también la falta de información por parte de las mujeres campesinas de sus derechos. Si bien el estudio señala que en el ámbito latinoamericano se están consolidando las organizaciones de mujeres rurales también nos dice que uno de los problemas en todo el engranaje de aplicación de las políticas publicas es el desconocimiento por parte de las mujeres de su situación jurídica y de sus derechos.

Así, la igualdad formal se traduce de manera muy diversa en políticas en el contexto de las reformas neoliberales. En algunos países como Ecuador el nuevo código agrario si bien ya no considera al varón jefe de hogar como único destinatario de la titulación de la propiedad, tampoco establecen ninguna medida explicita sobre la igualdad de oportunidades entre hombres y mujeres puesto que asume la figura de "personas naturales y jurídicas". Este no es el caso de Bolivia en donde el marco normativo hace explícito la igualdad entre hombres y mujeres.

Esta misma brecha aparece al examinar el tema de la herencia, principal fuente de obtención de tierra para las mujeres, en donde las autoras observan una profunda distancia entre normas igualitarias y practicas locales. Demuestran por ejemplo como sistemas de herencia bilateral igualitaria- en la forma, entran en contradicción con patrones de residencia virilocal y esto determina a la larga que las mujeres se retracten de un reclamo sobre la propiedad de la tierra.

Por otro lado, dentro de este mismo proceso al examinar las diferentes políticas emprendidas por los Estados respecto a la titulación: conjunta, individual y de acción afirmativa para las mujeres jefes de hogar, las autoras demuestran que si bien algunas de ellas han representado un mayor acceso a la propiedad para las mujeres, como en el caso colombiano con la titulación conjunta obligatoria, el sustento de estas políticas no es un reconocimiento explícito de la equidad entre hombres y mujeres. Estas políticas se legitiman en todos los casos ya sea con un discurso a favor de bienestar de los niños, de la reproducción de la familia, para contrarrestar situación de violencia, de migración de los hombres, entre otros, pero nunca como un derecho de las mujeres. Es decir, el discurso de la mujer vulnerable prima por sobre el discurso de los derechos de la mujer.

Un segundo tema que me gustaría resaltar del libro es el uso del concepto de empoderamiento y su relación con la propiedad. El empoderamiento es una palabra que empieza a formar parte del sentido común del discurso del desarrollo y su uso ha estado asociado cada vez mas como lo señalan las autoras con bienestar, estrategias de combate a la pobreza, participación social pero no necesariamente ha estado relacionado con la posesión de bienes materiales. Las autoras usan al empoderamiento como un proceso no lineal, contingente a las experiencias individuales, sociales y culturales de cada persona o grupo. Esto implica fundamentalmente una visión del poder no solo como subordinación sino como un potencial transformador. Lo que me parece interesante de la investigación es el argumento de cómo este proceso no puede sino estar estrechamente ligado con la propiedad, no sólo con el acceso a recursos, como usualmente se lo entiende, sino con el control y propiedad de los mismos, en este caso la tierra, poniendo al centro de la discusión la relevancia de los factores materiales y de la redistribución para el empoderamiento.

Retomando las reflexiones de algunas economistas feministas sobre la autonomía económica y su relación con mayores niveles de negociación en el hogar, la comunidad y la sociedad, las autoras sostienen la importancia de la propiedad y control de la tierra como un mecanismo fundamental que fortalece la capacidad de negociación de las mujeres al incrementar lo que las autoras denominan la capacidad de resguardo. La propiedad en ese sentido es una forma de empoderamiento de las mujeres rurales, una estrategia para alcanzar una mayor participación en la toma de decisiones en la familia, la comunidad a nivel de sus organizaciones y por tanto una ciudadanía mas acabada.

En ese sentido, la propiedad y el empoderamiento son procesos concretos encaminados a disminuir la brecha entre igualdad formal e igualdad real. Aquí, el interés central es demostrar la relevancia de los bienes materiales para alcanzar mayores niveles de autonomía y de autodeterminación de las mujeres y cómo este proceso de afirmación coadyuva en mayores niveles de bienestar para ellas y sus hijos. 
Me parece importante resaltar la forma en que las autoras utilizan el concepto de empoderamiento, éste aparece como un proceso social, dependiente de cambios y políticas estructurales y no solo de procesos identitarios individuales. Al mismo tiempo es un proceso que afecta directamente el entorno inmediato de las mujeres, cambia sus relaciones familiares y sus actividades al interior de su comunidad. En otras palabras nos llaman la atención para volcarnos a un tratamiento de la discriminación de género desde los ámbitos estructurales, de las políticas publicas y de la economía, de la relación con el Estado y con el mercado. Es decir cómo el empoderamiento de las mujeres debe disputar espacios con el poder económico y político además de los identitarios. Aspectos que si bien los han mencionado las feministas la practica del desarrollo tiende a olvidar.

Me parece que subrayar la relevancia del control y propiedad de la tierra para el empoderamiento vuelve a poner sobre el tapete la discusión sobre la creciente importancia de los derechos económicos y sociales de las mujeres en el marco de las políticas neoliberales en América Latina. Tema que ha sido central para las feministas latinoamericanas y las ha diferenciado de los procesos reivindicativos del feminismo del norte. Pero además de ello, se analiza la estrecha relación entre la demanda por los derechos económicos y sociales, en este caso el control y propiedad sobre la tierra y los temas del reconocimiento, la profunda imbricación entre discriminación material y desconocimiento o desvalorización de las diferencias que implica el género. En otras palabras, cómo estas diferencias se pueden transformar en desigualdades. El estudio me parece es un ejemplo sistemático de cómo se entretejen elementos culturales y económicos que se refuerzan mutuamente para producir desigualdad.

En tercer lugar, me gustaría comentar sobre la tensión entre demandas étnicas y demandas de género en el contexto del derecho a la tierra que las autoras presentan al analizar los países con mayor población indígena. Este capítulo es un esfuerzo especialmente valido para entender un matrimonio difícil, de intereses bifurcados, y en muchos casos infeliz para las mujeres. En efecto, el capitulo analiza los avances en las reivindaciones étnicas respecto a la tierra y la legitimidad que ha logrado el tema de la propiedad colectiva como la garantía indispensable para la supervivencia de los pueblos. Pero también señala que en muchos países estos avances han sido ciegos al género. Esto ha implicado contradicciones entre el respecto a los usos y costumbres, a la autoridad ancestral y el reconocimiento de que varios de estos sistemas culturales discriminan y excluyen a las mujeres. Las autoras analizan críticamente el discurso étnico sobre la estrecha identificación entre mujer y naturaleza destacando que si bien existe un reconocimiento simbólico importante para las mujeres éste por el momento no se traduce en mayores niveles de participación de las mujeres en los espacios de toma de decisión, en la política comunal y tampoco en mejorar el acceso y control sobre bienes económicos de las mujeres campesinas.

En ese sentido el capítulo concluye señalando el complejo desafío de las organizaciones de mujeres indígenas que están cada vez más llamadas a reconstruir esta articulación de manera que las beneficie, sin renunciar a sus derechos como pueblos.

Para terminar quisiera señalar que además de los debates en que nos permite incursionar el libro, una de las cualidades fundamentales del estudio es precisamente su perspectiva comparativa. Me parece necesario resaltar que los estudios de género en América Latina rara vez han emprendido ese tipo de empresa, la gran mayoría se ha centrado en los espacios nacionales y con ello no hemos podido sino producir muy poco conocimiento de la región sino es con un enfoque acumulativo más que comparativo. El mérito de este trabajo es precisamente el haber delineado ejes comparativos pertinentes y haber desafiado las dificultades que este tipo de enfoques presenta para el proceso investigativo; me refiero a las limitaciones en cuanto a la información disponible, la incoherencia de las fuentes, el desigual desarrollo de los estudios agrarios y de género en los distintos países analizados, entre otros. La estrategia comparativa adoptada permite brindar una mirada general y particular al mismo tiempo que pocas veces hemos logrado en los estudios de género en América Latina.

1 Próximo a salir en ingles como Empowering Women: Land and Property Rights in Latin America (Pittsburgh: University of Pittsburgh Press, 2001) y en traducción al portugués por Editora da Universidade, Universidade Federal do Rio Grande do Sul.

GIOCONDA HERRERA 


\section{Práticas de cuidado e trabalho docente}

No coração da sala de aula: gênero e trabalho docente nas séries iniciais

CARVALHO, Marília Pinto de.

São Paulo: Xamã/ Fapesp, 1999. 247 p.

Há algo de diferente no ensino das séries iniciais do ensino fundamental, em comparação com outros níveis de ensino? O fato de ser um local de trabalho com grande maioria de mulheres desempenhando a função docente confere alguma peculiaridade a este ambiente? $\mathrm{O}$ que significa ser mulher professora, principalmente quando essa prática se realiza nas primeiras séries do ensino fundamental? E como decifrar esse fazer diário, dissolvido nas rotinas escolares e muitas vezes sufocado pelos controles, pelos preconceitos e por pequenas disputas de poder? Essas são algumas das questões que orientam o estudo de Marília de Carvalho, elaborado originalmente como tese de doutorado, defendida na Faculdade de Educação da USP em 1998 e transformada em livro no ano seguinte.

A partir de um longo contato com algumas professoras e um professor das séries iniciais de uma escola pública da cidade de São Paulo, realizando entrevistas e observações, a autora contribui para um melhor entendimento das funções docentes, das relações professor/aluno e das relações de gênero dentro e fora da escola. A reflexão acerca do cuidado é um dos aspectos mais marcantes dessa pesquisa, conceito de inúmeras significações, que é aqui detalhado tanto em relação a estas várias conotações teóricas quanto em relação a seus múltiplos significados nas práticas dos professores.

O livro começa com um mapeamento de várias concepções ligadas ao gênero, deixando bastante claros os pressupostos teóricos adotados pela autora ao longo de sua investigação. A idéia de maternação, proposta por Nancy Chodorow, o desenvolvimento moral e a ética do cuidado tra- balhados por Carol Gilligan, as elaborações muitas vezes identificadas como feminismo da diferença, defendidas por várias autoras $e$, finalmente, concepções de autores como Joan Scott e Robert Connell são alvo de análises críticas e também fonte de colaborações para o arcabouço teórico construído ao longo da pesquisa.

Em seguida, o conceito de cuidado é analisado mais aprofundadamente, também sob o ponto de vista de vários autores, atuantes em diferentes áreas do conhecimento. A autora faz uma reconstrução desse conceito, considerando-o como uma construção social. Tenta afastar conotações de cunho universalista e a-histórico, negando serem as atitudes de cuidado referentes unicamente às mulheres, ou mesmo exclusivas de certos grupos sociais. Para isso, foi elaborada uma contextualização tanto para a origem histórica das práticas de cuidado, quanto para outros elementos que devem ser considerados nas análises das práticas escolares: a questão social, a de gênero e mesmo a relação entre adultos e crianças.

Uma especificidade do estudo é a iniciativa de compor a teoria e a empiria. Embora a autora trate alguns aspectos teóricos de maneira mais aprofundada no início do livro, como uma opção para a exposição de pressupostos e concepções que fundamentaram sua investigação, observase que a construção de idéias ocorre de maneira concomitante entre a esfera teórica e a empírica. Dessa forma, o trabalho não tem como característica somente a discussão incansável sobre a teoria e, do mesmo modo, não traz apenas dados empíricos dispersos. Há um equilíbrio entre essas duas esferas, e a leitura torna-se com isso bastante agradável e interessante.

Quanto ao referencial empírico, de abordagem etnográfica, pode-se verificar a explicitação e as justificativas dos procedimentos metodológicos escolhidos pela autora, bem como as dificuldades e os sentimentos que perpassaram o período de estudo. As relações entre a pesquisadora e as pessoas envolvidas no trabalho escolar também se encontram presentes no texto, bem como as modificações ocorridas nessas relações em função de um maior tempo de convivência.

Tem-se então a oportunidade de entrar em contato com os relatos sobre a atividade profissional de quatro professoras e um professor, relatos 
que conseguem delinear muito bem seus perfis individuais, seus posicionamentos e suas práticas pedagógicas. Além disso, dada a enorme dificuldade de se obter depoimentos pessoais, o que requer a construção de uma relação de confiança entre a pesquisadora e os depoentes, pode-se dizer que a autora teve sucesso em sua aproximação a certos acontecimentos da vida pessoal e profissional de cada um, facilitando assim o entendimento de determinadas situações e da atuação dos participantes.

Em todos esses relatos de trabalho pedagógico estão presentes as práticas de cuidado, na concepção adotada pelo estudo, e é interessante verificar como a autora apresenta os diferentes graus de significado e de importância dessas práticas na docência de cada um dos professores envolvidos na pesquisa. Torna-se bastante clara também a vinculação dessas práticas de cuidado com a natureza relacional da atividade docente, analisada no livro sob o aspecto da significativa afetividade observada entre, de um lado, o professor e as professoras mencionadas e, de outro, seus alunos, verificada em suas várias formas de expressão.

O conceito de cuidado aparece então como parte daquilo que é considerado pelos sujeitos um bom trabalho pedagógico e que pode ser observado, de forma geral, tanto no desempenho das professoras quanto no do professor participante, eliminando a idéia de que tal categoria faria parte apenas do conjunto de características femininas.

Considerando que o conceito de profissionalismo costuma estar associado muito mais à masculinidade, uma vez que se espera dos indivíduos técnicas e domínio de um determinado campo do saber, verificou-se que para as professoras investigadas, este conceito parecia definirse a partir do envolvimento pessoal, da realização e do prazer obtido no trabalho. Mesmo assim, as dimensões intelectuais eram sempre consideradas e mostravam que todos os sujeitos envolvidos se preocupavam também com ensinar, transmitir conteúdos, formas de raciocínio e técnicas, especialmente porque era de conhecimento geral que a desvalorização da carreira do magistério muitas vezes surge ao se levar em conta apenas o lado do envolvimento pessoal.

Por outro lado, por se associar muitas vezes o cuidado infantil à femininidade, constatou-se que o professor (homem) investigado apresentava maiores dificuldades com relação a sua prática docente. Porém, ao mesmo tempo, tinha maior liberdade para se distanciar desse conceito, o que, no caso das mulheres, ocasionava uma certa culpa.

Segundo a autora, essas práticas de cuidado, embora marcantes no trabalho docente com crianças, integram-no de forma contraditória e sem Ihe conferir legitimidade profissional, passando geralmente despercebidas em muitas pesquisas acadêmicas, porque não possuem estatuto teórico e dificilmente se constituem em objeto de estudo. No entanto, ficou patente ao longo dessa investigação a necessidade de se continuar estudando tais práticas, já que elas podem estar estreitamente vinculadas ao trabalho pedagógico das professoras e professores das séries iniciais do ensino fundamental.

Ao longo de toda a elaboração teórica e empírica apresentada no livro, nota-se a discussão de questões importantes que acabam fragilizando algumas polaridades presentes no discurso pedagógico de muitos professores e mesmo em certas produções acadêmicas, polaridades que associam certos atributos como a afetividade, intensas relações interpessoais, o comportamento maternal e o cuidado à femininidade e, por outro lado, a racionalidade, as relações pessoais mais distantes, a disciplina e a competência profissional à masculinidade.

Além disso, abordando mais especificamente a freqüente associação realizada entre o cuidado, o comportamento maternal e a femininidade, em oposição a padrões de atuação masculinos, que não apresentariam tais características, as práticas de cuidado verificadas parecem ser próprias do ensino primário, não correspondendo, portanto, a uma transposição direta de práticas domésticas para o ambiente escolar. Marilia de Carvalho afirma ter ocorrido, então, ao longo do tempo, uma construção social de pressupostos comuns a um ideal de mãe e de professora primária, realizado tanto na escola quanto fora dela. Tais práticas de cuidado estariam associadas à feminilidade e à maternidade, o que remete a uma concepção de infância, a um conceito de cuidado infantil e a normas sobre a adequação das mulheres a essas tarefas. Esse modelo ideal de professor seria produzido, transmitido e reproduzido no interior da própria escola, como parte de uma cultura escolar partilhada pelos que ali trabalham. Uma dimensão do conceito de feminização aqui apresentada é referente à escola e ao ensino primários, independentemente do sexo do profissional docente.

Pode-se dizer que as reflexões e análises contidas nesse trabalho condensam, com grande harmonia, um longo caminho de inquietações te- 
óricas e uma perspicaz prática de pesquisa. Além disso, suas contribuições não se esgotam apenas na compreensão do fazer docente à luz das relações de gênero e do universo relacional que caracteriza essa profissão. O estudo apresenta também um quadro rico e cuidadoso da cultura escolar e dos aspectos menos visíveis das rotinas e afazeres em que professores e professoras, por caminhos diversos e muitas vezes contraditórios, procuram tornar-se sujeitos de sua própria prática.
Por tudo isso, o trabalho de Marilia de Carvalho deve figurar como referência básica não só para os estudos sobre a educação fundamental, como também para todos aqueles que se interessam por uma reflexão mais aprofundada sobre as relações de gênero.

\section{Ações afirmativas, mulheres e mercados de trabalho}

\section{Mulher e Trabalho: experiências de ação afirmativa}

DELGADO, Dídice, CAPELLIN, Paola \& SOARES, Vera (orgs.)

São Paulo: ELAS/Boltempo Editorial, 2000. 144p.

Parte conclusiva de um programa de seminários e publicações mais amplo, de dois anos de duração, esse livro reúne os aportes apresentados por especialistas de diversos países no seminário internacional As mulheres no mundo do trabalho: experiências internacionais de ações afirmativas, realizado no Brasil de 14 a 19 de abril de 1997, organizado pela Fundação Friedrich Ebert-lldes (FESIldes), Universidade Federal do Rio de Janeiro (UFRJ), Elisabeth Lobo Assessoria (Elas), e Centro Feminista de Estudos e Assessoria (CFEMEA), com apoio de diversas instituições internacionais e nacionais (sindicais, empresariais, governamentais e não governamentais).

O Seminário teve por objetivo o de "possibilitar o contato do público brasileiro com experiências consolidadas de ação afirmativa que revelassem: (1) a viabilidade da medida como um caminho para a construção da igualdade de oportunidades entre homens e mulheres no trabalho; (2) a participação dos diferentes atores sociais na construção e na implementação das experiências; (3) o arcabouço legal no qual se inserem as ações afirmativas; (4) as dificuldades e os desafios da implementação das propostas em cada realidade" (p. 9)

Martine Voets discorreu sobre a ação afirmativa como parte da política de igualdade de oportunidades desenvolvida pela União Européia; Jacqueline Laufer analisou a experiência francesa na matéria; Etta Olgiati comentou o caso italiano; Kimberley Pate abordou o tema das ações afirmativas nos Estados Unidos; e finalmente Laís Abramo apresentou linhas de reflexão sobre as mudanças nos mercados de trabalho latino-americanos e as condições das mulheres.

O livro é introduzido pelas organizadoras, integrantes da Elas e da UFRJ, com o texto "A mulher no mundo do trabalho: Perspectivas e desafios para construir a igualdade de oportunidades no Brasil". Tributárias de uma publicação anterior do mesmo programa,' as organizadoras do livro começam por definir $\mathrm{O}$ conceito de ações afirmativas: "A afirmação do princípio de igualdade de oportunidades entre homens e mulheres e sua aplicação no mundo do trabalho já tem uma história no cenário internacional. São denominadas ações afirmativas essas políticas que têm como meta corrigir antigas e novas discriminações" (p. 11).

As organizadoras contam essa história, cujos primórdios vinculam-se à eliminação de todos os elementos discriminatórios contidos nas legislações, seguidos de um esforço adicional para estimular, através de procedimentos práticos, a efetiva mudança nos comportamentos discriminatórios nos locais de trabalho: "A força moral e coercitiva 
dos mecanismos punitivos legais muitas vezes não consegue ser propulsora da inovação de comportamentos. Assim, o desenho de metodologias, de planos e de estratégias concretas de políticas de intervenção foi um propósito comum em vários contextos nacionais nos anos $80^{\prime \prime}$ (p. 12).

Segundo Cappellin, Delgado e Soares, o desafio pragmático da mundialização da economia, com suas exigências no que diz respeito à adequação das organizações produtivas, foi o cenário que estimulou alguns agentes econômicos a aderirem a esse tipo de estratégia, com o intuito de experimentar uma aliança entre a rentabilidade dos negócios e o êxito de novas estratégias de recursos humanos que promovessem a igualdade de oportunidades. Para as organizadoras da publicação, "[a] leitura das experiências internacionais oferece outro ensinamento: a implementação das ações afirmativas pressupõe uma vontade políitica socialmente compartilhada de realizar inovações" (p. 14). Nesse sentido, são levantadas as batalhas ganhas desde a sanção da Constituição de 1988 pelos diferentes setores e atores interessados (governamental, parlamentares, movimento de mulheres, sindicatos, organizações empresariais, etc.), como sinais de um processo de mudanças em direção a uma abertura maior para formular políticas de igualdade de oportunidades no Brasil.

A seguir, encontramos 0 texto de Martine Voets, "A estratégia européia para a ação afirmati$v^{\prime \prime}$ (p. 21), que possibilita uma compreensão mais ampla dos textos de Laufer ("Igualdade profissional e ações afirmativas") e de Olgiati ("As ações afirmativas na Itália e um olhar sobre a Europa"), referidos às experiências nacionais francesa e italiana, respectivamente. O grande ponto de destaque, considerando esses três textos em conjunto, analisados em contraposição à experiência nos Estados Unidos, é a importância dos processos de integração supra-nacional como motor propulsor da adoção de medidas de ação afirmativa nos diversos países europeus, com grande participação dos estados em sua aplicação nacional.

A história das ações afirmativas na Europa encontra-se pautada pela história dos acordos de integração que, no caso específico das diretrizes para a consecução da igualdade de oportunidades de gênero nos mercados de trabalho, começa em 1957 com o próprio Tratado de Roma (que estabeleceu a Comunidade Econômica Européia): "[o]s artigos desse tratado diziam respeito essencialmente às questões econômicas. As disposições da legislação social européia referiam-se a aspectos muito restritos, tais como a liberdade de movi- mento das pessoas e a livre concorrência. Foi nesse contexto que nasceu a legislação européia sobre a igualdade de remuneração entre trabalhadores dos sexos feminino e masculino. Assim, as disposições do artigo 119 do tratado foram adotadas com a finalidade de evitar deformações na concorrência entre os países, devido aos baixos salários pagos às mulheres" (Voets, p. 22).

Os anos 70 trouxeram a preocupação com formular, nacionalmente, o arcabouço legal que pudesse gerar maior igualdade de oportunidades nos mercados de trabalho envolvidos na Comunidade. Os anos 80, após a comprovação de que o arcabouço legal era necessário porém não suficiente, trouxeram as primeiras preocupações com a promoção da igualdade e, conseqüentemente, com as medidas de ação afirmativa. Finalmente, o viés dos anos 90 está constituído pela compreensão das condições de trabalho das mulheres no contexto mais amplo da condição das mulheres na sociedade (preocupações com a saúde e a segurança das gestantes, licença parental etc), pela construção de parcerias (mobilização e estabelecimento de acordos mediante negociações de parceiros na vida econômica e social) e pelo mainstreaming ou transversalidade (inclusão da problemática das relações de gênero como principio transversal integrado à formulação e à implementação de todas as políticas e planos de ação). "Uma década de ativo fomento à ação afirmativa para as mulheres trabalhadoras produziu um considerável conhecimento prático sobre esse assunto, que era relativamente inexplorado até o começo da década de 1980" (Voets, pág. 36). Na última década do século passado, a Comunidade desenvolveu diversas iniciativas com a finalidade de disseminar e debater estes conhecimentos, entre elas, a realização de seminários e conferências, a consolidação e a circulação da informação, o financiamento de projetos de pesquisa, o apoio a projetos inovadores de ação afirmativa, o estabelecimento de redes para a implementação de programas específicos.

O caso francês resulta ilustrativo para compreender a importância do papel do estado na consecução dos objetivos colocados na aplicação de medidas de ação afirmativa, principalmente no que diz respeito à promoção, desde 1983, de três tipos de instrumentos: (1) a introdução do princípio de negociação específica no tocante à igualdade profissional entre homens e mulheres nas negociações coletivas; (2) a obrigação das empresas com mais de cinqüenta empregados, de elaborar um relatório anual das condições de 
emprego de mulheres e homens; (3) a negociação de planos de igualdade, com previsão de auxílio financeiro por parte do estado aos planos exemplares.

A partir de 1987, esse conjunto de instrumentos foi complementado por outros dois instrumentos de promoção da igualdade profissional: o contrato para empregos mistos e os acordos interprofissionais.

"Esse contrato para empregos mistos permitiria que empresas com até seiscentos empregados recebessem subsídios do Estado para financiar $50 \%$ dos custos de formação e $30 \%$ do salário durante a formação de uma mulher contratada ou promovida para um emprego usualmente exercido por homens em $80 \%$ dos casos. Enquanto a negociação coletiva relativa à igualdade profissional prevista pela lei de 1983 dizia respeito antes de tudo à empresa, os acordos interprofissionais sobre a igualdade profissional foram assinados em 1989, preconizando a incorporação de objetivos de igualdade profissional nas negociações entre setores sobre as novas tecnologias ou sobre a duração no trabalho" (Laufer, p. 45).

Já o caso italiano especifica as estratégias institucionais dirigidas à adoção de programas de ação afirmativa de caráter voluntário, ilustrando esta análise através de uma grande empresa, a Italtel (a maior empresa italiana de telecomunicações). A experiência pioneira da ltaltel aconteceu num ciclo caracterizado por importantes transformações em sua estrutura técnico-organizativa e obedeceu a uma combinação de diversos fatores: o compromisso pessoal da administradora com as políticas de igualdade, o salto tecnológico da empresa, suas conseqüências negativas sobre o pessoal - especialmente sobre as mulheres -e o compromisso de um grupo de sindicalistas de Milão com as diretrizes européias sobre igualdade de oportunidades no trabalho.

A seguir, Olgiatti comenta o resultado da análise horizontal de 18 experiências de ação afirmativa em empresas, apresentadas no Fórum Europeu sobre as Ações Afirmativas (primeira atividade anual de um grupo de especialistas constituído pela Comissão Européia para os Direitos da Mulher em 1994):

"Em primeiro lugar, essa análise confirma que os programas de ação afirmativa podem constituir um ponto de encontro real entre as necessidades de empresas eficientes e competitivas e as aspirações profissionais e as necessidades das pessoas. A análise também forneceu indicações significativas sobre as variáveis que influenciam positivamente a implementação de ações afirmativas nas empresas" (Olgiatti, p. 75).

As variáveis consideradas foram: fatores exógenos (como as mudanças no mercado, as dinâmicas do mercado de trabalho e o quadro institucional), fatores endógenos (como a inovação tecnológica, as estratégias organizativas, as parcerias sociais e a adesão da alta direção da empresa com as políticas de igualdade), instrumentos (modalidades de implantação e procedimentos, opções organizativas, entre outros aspectos) e conteúdos das ações afirmativas (voltadas para a introdução de mudanças culturais, que visam à superação da segregação vertical e da horizontal para a conciliação entre vida profissional e vida familiar, para garantir o pleno respeito à dignidade humana, entre outros conteúdos possíveis).

Por trás da experiência dos Estados Unidos aparece outro tipo de integração almejada: a integração à sociedade daqueles que lá são denominados "as minorias" (mulheres, negros, "latinos", índios, asiáticos, entre outros). A análise do caso norte-americano traz à tona não só uma outra origem, mas também outros componentes possíveis na adoção de medidas de ação afirmativa: a força da sociedade civil e o papel do litígio e do acordo judicial.

Muito especialmente envolvidos com a questão racial,

"[o]s programas de ação afirmativa para mulheres foram igualmente limitados nas decisões da Suprema Corte. Na ação da 'Universidade para Mulheres do Mississipi contra Hogan' (1982), a escola de enfermagem para mulheres foi processada por um homem que não foi admitido num programa de graduação sob o argumento de que a 
instituição violara a Cláusula de Proteção à Igualdade da 14ª Emenda da Constituição dos Estados Unidos. A Suprema Corte extinguiu a política da universidade de admitir apenas mulheres na escola de enfermagem, julgando que uma classificação por gênero somente seria válida se houvesse uma prova de que aquela política pretendia compensar muIheres por discriminação sofrida na enfermagem, em oposição a uma discriminação mais generalizada enfrentada na escola ou no emprego" (Pate, p. 91).

Após comentar brevemente os mitos e as realidades sobre as ações afirmativas e suas conseqüências, Pate analisa os efeitos produzidos pelos ataques às ações afirmativas durante o governo Clinton, principalmente a Proposição 209, "iniciativa popular anti-ação afirmativa" que os eleitores da Califórnia votaram em 1996. A mobilização da sociedade civil é ressaltada como via para proteger e ampliar as conquistas obtidas em prol da igualdade de oportunidades e pelo fim da discriminação e do preconceito.

A contribuição de Abramo tem características completamente diferentes. Após retratar as condições das mulheres trabalhadoras na América Latina entre 1970 e 1990, com base na análise dos dados produzidos pelo Projeto de Pesquisa Regional da Flacso, ${ }^{2}$ a autora se propõe a analisar algumas experiências atuais de inserção feminina nos mercados de trabalho. Com um enfoque analítico e crítico, fundamentado numa diversidade de pesquisas, Abramo desmonta algumas das crenças em torno dos supostos benefícios que trazem às mulheres trabalhadoras os processos de globalização, de flexibilização, de reestruturação produtiva, e de inovação tecnológica (principalmente no que diz respeito ao estabelecimento das cadeias produtivas).

A autora também desafia alguns dos mitos sobre as cadeias produtivas na América Latina, destacando sua real verticalização, sua assimetria de poder e de competitividade, e chamando a atenção para o fato de que a integração supranacional poderia trazer aspectos positivos e negativos. É importante permanecer atento a essas duas possibilidades, na hora de elaborar e implementar políticas públicas tendentes à superação da discriminação de gênero na área de trabalho e renda. Nesse sentido, Abramo afirma:

"Os processos de integração regional enfatizam a importância de introduzir essa perspectiva tanto na análise dos tecidos produtivos como na discussão das políticas públicas, em especial aquelas relacionadas aos processos de fomento produtivo, desenvolvimento econômico local e geração de emprego. Se é certo que entender esse tipo de articulação produtiva é cada vez mais importante para caracterizar a configuração real dos tecidos produtivos, também é certo que as cadeias (ou os clusters de empresas) não se limitam necessariamente a apenas um país (Gereffy, 1993). É muito provável que os processos de integração regional, como é o caso do Mercosul, estimulem (ou definam) os encadeamentos ao longo do territórios que abarquem mais de um ou vários países. Esse fenômeno pode apresentar aspectos positivos e negativos para o emprego em geral e o trabalho feminino em particular, dependendo das condições nas quais se desenvolva" (Abramo, p. 124).

A seriedade e a multiplicidade dos aportes contidos na publicação merecem uma leitura detalhada, meditada, que com certeza constituirá um estimulante motor de ricas e superadoras proposições no campo das políticas públicas de trabalho e renda com preocupações de gênero e justiça social.

Os artigos que compõem essa coletânea refletem sistematicamente avanços e retrocessos, êxitos e fracassos na procura da igualdade profissional entre homens e mulheres: quais os limites a serem respeitados para que uma ação afirmativa não contradiga o princípio da igualdade formal entre os indivíduos? Como mobilizar os diferentes setores socioeconômicos com o intuito de construir consensos em torno da necessidade e da positividade das ações afirmativas? Como evitar os aspectos negativos da reestruturação produtiva e o ajuste estrutural no sentido de impedir que 
a discriminação baseada nas concepções de gênero assuma nova cara e continue marcando a vida das mulheres?

A leitura do livro em seu conjunto permite recuperar alguns dos dilemas colocados aos formuladores e gestores de políticas públicas de trabalho e renda preocupados com os aspectos da diversidade da população economicamente ativa, e principalmente com a discriminação baseada no sistema de sexo/gênero. Alguns gestores optam por apresentar esse tipo de políticas aos empresários como um derivado do princípio de eficiência, e portanto como baseadas na competitividade. Com esse enfoque, atender a problemática da discriminação das mulheres no trabaIho significaria agir a favor do desenvolvimento econômico (crescimento e competitividade), do aumento da produtividade (produção de bens e serviços), da melhoria da imagem da empresa na sociedade (atingindo a circulação de bens e serviços) e da utilização adequada da multiplicidade e da variedade de recursos humanos disponíveis numa dada sociedade. No entanto, esse enfoque desatende o outro lado da moeda, igualmente importante, que é o compromisso social do empresariado, no que diz respeito à atenção da cidadania e do princípio de eqüidade. Essa ótica, em contrapartida, privilegia o desenvolvimento social (isto é, o crescimento econômico com redistribuição da renda), os direitos humanos e as liberdades fundamentais, a justiça e a harmonia social e a igualdade de oportunidades e opções. ${ }^{3}$
O livro ainda estimula a refletir sobre alguns pontos importantes para o desenvolvimento de políticas sociais mais justas:

- É preciso olhar a temporalidade da problemática de gênero (processos);

É preciso analisar a problemática em cada regiấo, setor de atividade, grupos de mulheres etc (público específico);

É preciso considerar diversos tipos de razões para negociar com diversos atores (objetivos);

Não há nem poderia haver uma única solução ou política pública para todas as mulheres.

Finalmente, podemos afirmar que esse livro constitui um subsídio fundamental para todos aqueles interessados na formulação, na gestão e na avaliação de políticas públicas na área de trabaIho e geração de renda (governo, empresários, trabalhadores, movimentos de mulheres, ongs, legisladores, organismos intergovernamentais, entre outros), bem como a pesquisadores comprometidos com a temática das relações de gênero no mundo do trabalho.

' Discriminação positiva. Ações Afirmativas: em busca da igualdade. Brasília/São Paulo: CFEMEA/Elas, 1996. 2 VALDES, Teresa, e GOMARIZ, Enrique. Mujeres latinoamericanas en cifras. Tomo comparativo. Santiago de Chile: Flacso/Instituto de la Mujer de España, 1995.

${ }^{3}$ Ver CUELLAR, Javier P. de et alli. Nuestra diversidad creativa. Informe de la Comisión Mundial de Cultura y Desarrollo. México: Unesco, 1997.

SILVIA CRISTINA YANNOULAS

\section{"A Bela Esquina": gênero e feminismo.}

\section{Falas de gênero}

SILVA, Alcione Leite da, SOUZA, Mara Coelho de Lago, e RAMOS, Tânia Regina Oliveira (orgs.).

Florianópolis: Mulheres, 1999. 343 p.

Marianne, olhando-se nos próprios olhos diante de um espelho - menos para se ver e mais para refletir sobre si mesma - fala em voz alta: "Pensem o que quiserem. Quanto mais vocês acreditam poder falar de mim, mais eu serei livre em relação a vocês. Às vezes, me parece que as no- vidades que aprendemos sobre as pessoas perdem logo o valor. No futuro, se qualquer um me explicar como eu sou — seja para me fragilizar ou para me tornar mais forte - eu não admitirei mais uma tal insolência". '

Marianne é uma criação ficcional de Peter Handke, uma personagem do romance La femme gauchère. Essa fala (emitida logo depois de um diálogo tenso com Bruno, o marido do qual ela, por sua vontade, se separa) sedimenta a ruptura e inaugura seu processo de solidão, de descoberta de si mesma.

A última frase da fala mencionada - extraída do contexto dessa intimidade entre Marianne e si mesma (seus olhos em seus próprios olhos no espeIho), individualidade e subjetividade extremas - 
poderia ser útil para esboçar a reação que os estudos de gênero prometiam diante de todas as definições, classificações, unificação em uma categoria -naturalizada, essencializada, ou pretensamente historicizada - , a Mulher, as mulheres.

Os estudos de gênero prometiam; cumpriram?

Essa indagação pode ser explorada na leitura da coletânea Falas de Gênero, que resultou do terceiro encontro Fazendo Gênero, admirável iniciativa da Universidade Federal de Santa Catarina. Admirável pela contribuição que vem oferecendo ao enriquecimento do campo de estudos de gênero e da teoria feminista no Brasil, pelas pesquisas que nele são apresentadas e por suas discussões teóricas. Também, pela continuidade que vem mantendo. O encontro Fazendo gênero 3, aconteceu de 13 a 15 de maio de 1998 no Centro de Ciências da Saúde da UFSC e teve como tema geral "Gênero e Saúde".

O livro, Falas de gênero, contém dezoito artigos, os quais estão entre uma Apresentação ${ }^{2}$ e um Posfácio. ${ }^{3}$ Apesar de não ter sido esse o meu percurso de leitura, sinto-me tentada a recomendar a leitura da apresentação e do posfácio antes da leitura dos artigos; depois, sugiro que se leia a apresentação de novo, os artigos e então o posfácio outra vez. Certamente ambos, apresentação e posfácio, dirão bem mais do conjunto de artigos e de suas questões do que esta resenha o fará. Os dezoito capítulos estão organizados em três partes - "Teorias", "Análises" e "Leituras" —, e o encadeamento é muito bem resolvido, inclusive pelo debate interno que sugere ao leitor, o que não é muito comum em coletâneas.

Na impossibilidade de detalhar todos os artigos, vou me concentrar nas discussões da primeira parte e na sugestão do debate possibilitado pelo encadeamento ao qual me referi. O primeiro e estimulante artigo é de Joan Scott, sobre a noção de experiência. Discutindo com autores como Raymond Willians e Thompson, entre outros, a autora reivindica ao mesmo tempo o aspecto discursivo da experiência e seu estatuto como fundamento inquestionável da explicação. Ao criticar o projeto de tornar a experiência visível, ela nos incita a pensar que é a própria produção desse projeto de conhecimento que caberia questionar. Para isso, a experiência não é considerada nem como interna nem como externa ao sujeito, ela o constitui; a experiência não adquire significados: ela não aconteceria fora de significados. Com essa crítica, retoricamente conduzida através de uma reflexão sobre a meditação autobiográfica de Samuel Delanay, o artigo de Scott interessa não apenas aos estudiosos de gênero, nem apenas aos historiadores (embora sejam estes seus interlocutores explícitos), mas também ao debate teórico das ciências humanas em geral. Se encontro nesse artigo a promessa bem cumprida dos estudos de gênero, questão a que me referi no início, Scott fica nos devendo maior extensão e precisão de frases muito jogadas, como "a linguagem é o local onde a história é encenada". Muitos talvez sentir-se-iam à vontade para inverter esta frase.

No artigo seguinte, Maria Ignez S. Paulillo contesta o que ela designa como maniqueísmo metodológico, ou seja, a dicotomização entre os positivistas e os não positivistas, e desafia alguns dos pressupostos feministas em sua rejeição ao positivismo. Rebatendo a associação entre positivismo e método quantitativo, ponto alto do artigo, a autora chama a atenção para os aspectos importantes de muitas contribuições cujos autores foram taxados de positivistas pela preocupação com o rigor das inferências e de demonstrações, por exemplo. É na relação entre objetividade e subjetividade que parece estar colocada a ênfase do artigo. Em primeiro lugar, ao criticar a defesa da subjetividade na elaboração do conhecimento científico a autora diz que esse pressuposto acaba adquirindo um estatuto tão universal quanto aquele que a objetividade teria para os positivistas.

Em segundo lugar, ela expressa sua dúvida sobre a capacidade atribuída à ciência, uma vez subjetivada, a decidir sobre valores. O que constituiria um falso passaporte para posturas críticas. $\mathrm{O}$ artigo, pela clareza e pela pontuação da crítica, abre um debate importante e que precisa ser aprofundado. Inclusive porque a relação - entre objetividade e subjetividade - que muitos acharam possível resolver com a intersubjetividade, com a objetivação da subjetividade ou com outras combinações mais recentes, ainda constitui um problema a resolver. E se ainda é necessário situar melhor a discussão crítica em relação ao feminismo, ela seria voltada à teoria feminista? às teorias feministas? a uma ou a algumas perspectivas teóricas que as orientam?

O artigo de Claudia de Lima Costa situa-se exatamente numa discussão de crítica ao positivismo (afirma inclusive sua derrocada desde os anos 60) e tem como tema o debate em torno da etnografia regida pela poética do poder, que conforme a autora deixaria em segundo plano 
uma política de poder no campo, particularmente problematizada a partir de uma perspectiva feminista. Entendendo que o feminismo deriva sua teoria de uma prática fundamentada na materialidade da opressão sofrida pelas mulheres (p. 78), Claudia de Lima Costa nos remete a algumas das tensões entre antropologia e feminismo, entre o trabalho de campo e o da escrita, entre uma genealogia masculina na antropologia e a contribuição de etnografias feministas, bem como aos impasses políticos da representação da alteridade. O artigo é instigante. Principalmente no critério que usa para a distinção entre a boa e a má etnografia, o qual se desloca dos procedimentos de condução da pesquisa e da escrita para sustentar-se no vínculo com o projeto éticopolítico que a sustenta. Mais especificamente ao sugerir práticas etnográficas alternativas, geradas por uma imaginação feminista (p. 94). E ainda porque complexifica seus próprios pressupostos e os dos textos com os quais dialoga. Entretanto, em alguns momentos, ao referir-se ao cânone antropológico, o artigo deixa de considerar os vários contextos de embates, clássicos ou contemporâneos, nos quais a antropologia se constitui. Assim, supõe como canônico o que alguns debates elegem como tal. Além do mais, creio que é preciso repensar afirmações como "a atitude imperial de Malinowski de falar com a voz do outro". A leitura de Os Argonautas do Pacífico Ocidental e de Baloma: o espírito dos mortos, mesmo para os críticos de Malinowski e do contexto colonial onde sua etnografia se fez possível, revela a preocupação com a transcrição (com minuciosa atenção lingüística) dos mitos e das fórmulas mágicas dos trobriandeses, com a viva descrição de suas crenças, que adquirem plena realidade na visita dos mortos às aldeias dos vivos, com a descrição minuciosa da técnica de construção das canoas e das trocas intertribais. Essas etnografias permitiram contestar pressupostos gerais sobre os "primitivos", bem como o caráter universal de um valor histórico (próprio do universo social do autor), o da lógica estritamente econômica da troca. Efeitos conceituais e políticos nada desprezíveis, particularmente na época em que essas obras foram publicadas.

Também em outros momentos a discussão sobre uma "genealogia feminina" na antropologia ou sobre uma "tradição feminina de escrita etnográfica alternativa" deixa de levar em conta que a trajetória da antropologia é marcada por escritas bem convencionais de antropólogas e escritas bem alternativas de antropólogos. O encontro da antropologia com a literatura - na obra de Leiris por exemplo - resulta numa escrita antropológica "não canônica". Seria feminina? Para quem já leu Sexo e Temperamento, de Mead, a leitura do outro texto da mesma autora, escrito anos depois, "Macho e Fêmea", é desconcertante. No primeiro, através de uma etnografia de três sociedades relativamente adjacentes, Mead mostra a arbitrariedade de valores como feminino e masculino em relação à diferença biológica do sexo. Ou seja, não haveria uma conformidade, nem uma continuidade, entre o sexo biológico e o que a sociedade the atribuía como valor. Ou seja, não haveria uma conformidade nem uma continuidade entre o sexo biológico e o que a sociedade the atribuiria como valor. Assim, a divisão de trabalho e as qualidades que compõem as pessoas, como exemplos, dependeriam deste valor cultural (o lugar destinado ao gênero) e não do sexo biológico. Essa perspectiva mais arrojada se perde no livro de 1949. Embora mostrando como as sociedades investem culturalmente nos corpos e nos gestos das crianças para torná-las homens ou mulheres, e em várias partes do mundo, Mead não repõe com a mesma ênfase o argumento anterior e vai buscar as lições que a ciência poderia dar em benefício da complementaridade (em oposição à competitividade) entre os dois sexos e seus diferentes "dons" (o termo é dela). Trata-se aqui mais de integrar as diferenças a serviço da humanidade. Ou seja, reconhecemos nesse segundo livro de Mead o contexto político da época (logo após o final da Segunda Guerra Mundial). Enfim, genealogias e gerações, e mesmo gênero, parecem pedir para serem lidos em seus sentidos, raramente presumíveis a priori, de um contexto complexo de relações.

A densidade do artigo de Claudia de Lima Costa, a amplitude de sua discussão bibliográfica, sua reflexão criativa no campo do feminismo e principalmente a contestação de uma supervalorização da poética do poder são um convite aos interessados numa interlocução estimulante. Aliás, o pressuposto nuclear do artigo é retomado num dos capítulos da última parte, "Leituras", no qual Simone Pereira Schmidt, a partir de duas páginas poéticas dedicadas à celebração da vulva, no caderno Mais! (suplemento da Folha de São Paulo), de julho de 1997, afirma: "diferentemente do que pensa Costa, pretendo defender a eficácia política de uma poética do lugar". Assim, como eu indicava no início, não só o encade- 
amento dos artigos sugere um debate. Há também um debate explícito. $\mathrm{O}$ que ainda mais recomenda esse livro.

Mas, voltemos à seqüência do livro. O artigo seguinte ao de Lima Costa é "A pesquisa como prática de cuidado na emancipação da Mulher". Nele, Alcione Leite da Silva defende o que o próprio título indica. Remetendo aos efeitos da crítica feminista a um modelo de ciência (particularmente a objetividade, a verdade e a separação entre teoria e prática), a autora situa seu referencial numa vertente feminista pós-moderna. Em função disso, explicita em seguida a definição de feminismo que defende, ou seja "um compromisso político, uma consciência, uma forma de pensamento e uma práxis" (p. 106). Depois, qualifica o feminismo, o pós-moderno. Uma vez situada sua perspectiva, a autora refere-se mais detalhadamente a sua sugestão da pesquisa como prática de cuidado. Como tal, a pesquisa se deslocaria de uma preocupação com o avanço do conhecimento ou da resolução de uma questão empírica para o compromisso entre a pesquisadora e as participantes. Nesse encontro, afirmado como dialógico, o propósito fundamental seria estimular uma reflexão sobre a vida cotidiana, sobre os processos políticos e sociais, numa relação de reciprocidade e intimidade, no estímulo à mudança. A autora, durante o artigo, vai explicitando o que seria a qualidade da pesquisa proposta através inclusive de noções como emancipação, ativismo político, espaço para o desejo e abertura de esperanças e possibilidades. Ou seja, a pesquisa como "instância de emancipação política e social" (p. 116), ou ainda como meio para a criação de "comunidades transformadoras de diferenças" (p. 114). Não é a primeira vez que a pesquisa é afirmada como meio para a prática política (aquela, por exemplo, que já foi chamada de pesquisa-ação). Mas nesse artigo, a incógnita é o estatuto da noção de conhecimento. Pois se "o papel da pesquisadora deixa de ser avançar o conhecimento ou de resolver uma questão empírica" (p. 110), e se um dos desafios para a pesquisa feminista é que não "há clareza de como constituir um conhecimento de forma emancipatória" (p. 115), ou ainda se a reação ao que é designado como "modelo científico tradicional" é uma pesquisa que difira do "modelo patriarcal", tudo indica, estamos também diante de um diálogo com os "modelos" e com conhecimentos científicos.

O último artigo dessa primeira parte, "Identidade: a fragmentação do conceito", sintetiza al- guns dos impasses em torno de identidade na teoria social e ressalta a importância do recurso à psicanálise. Esse recurso, conforme a autora, Mara Coelho de Souza Lago, permitiria tornar mais complexa a noção do sujeito como construção consciente considerando a de sujeito inconsciente e a de sujeito do inconsciente (p. 122). Nessa perspectiva - no que se desloca para a noção "de constituição simbólica do sujeito enquanto significado pela cultura" — não caberiam as dicotomias sociedade/indivíduo/cultura. A identidade, como construção imaginária e organização ficcional, não suporia a separação entre um eu e a sociedade e a cultura (no que a autora tem razão, pois muitas teorias a efetuam e assim criam para si mesmas os problemas de como juntar o que foi separado), nem a fragmentação do sujeito particular em sua relação com a fragmentação e a multiplicidade do social. A identidade seria assim concebida como história de vida, com um mínimo de coerência e unidade interna imaginária.

O argumento é estimulante para os que se vêem diante das teorias que ainda procuram resguardar o conceito de identidade, ou diante daquelas que praticamente o dissolvem; para os que ainda não se convenceram de que as redes objetivas em que se situam os agentes seriam suficientes para tornarem mais compreensíveis as trajetórias de sujeitos particulares e os sentidos dessas trajetórias. Mas também no que nos incita a continuarmos colocando sob suspeita o que Scott, em seu artigo nesse livro, chama de evidência e autenticidade das experiências e de naturalização e universalidade de categorias "como homem, mulher, preto, branco, heterossexual ou homossexual ao tratá-las como características inerentes aos indivíduos" ( $p$. 30). Entretanto, nesse particular, o artigo de Souza Lago apenas indica algumas boas perguntas (inclusive sobre a identidade de gênero dos transexuais) e no final pára nos limites de uma perspectiva da identidade como atribuição social. No plano políti$\mathrm{co}$, onde boa parte das identidades travam sua afirmação, a atribuição não apenas é uma das pedras do tabuleiro onde o jogo se faz, mas também, e principalmente, ela própria pede a consideração sobre relação entre atribuição e a auto-atribuição, as mediações que sustentam as pertinências e os repertórios narrativos disponíveis para a "construção imaginária e organização ficcional".

Na segunda parte do livro, "Análises", os artigos tratam de políticas públicas e de saúde, escritos por Eva Alterman Blay, Clair Castilhos Coelho, Estela Maria Leão de Aquino; sobre a criminalização de práticas abortivas, por Joana Maria Pedro; so- 
bre novas formas de paternidade, por Maria Juracy Toneli Siqueira; sobre a incursão da medicina no debate sobre a sexualidade no início do século no Brasil, por Maria Bernardete Ramos Flores; e sobre os desafios teóricos da corporalidade postos pelas ações dos transgender, por Sônia Weidner Maluf.

Na terceira e última parte, "Leituras", os artigos tratam de diários femininos, como faz o de Maria Teresa Santos Cunha; de uma nova matriz narrativa sobre paternidade e maternidade na literatura feminista contemporânea, como o escrito por Susana Bornéo Funck; de um poema de Vinícius de Moraes como meio de entender as contradições da masculinidade definida como machismo, numa leitura de Tânia Regina Oliveira Ramos; e finalmente de uma belíssima incursão, a de Zahidé Lupinacci Muzart, no diário em formas de cartas à filha escrito por Calamity Jane, pessoa-personagem do Velho Oeste.

Como se pode ver, o campo de estudos de gênero e do feminismo é amplo, as Falas de Gênero são múltiplas e ressoam em lugares e linguagens distintos. Em algumas linguagens, recusa-se às totalizações prévias e naturalizadas, que em outras se fazem presentes. Em alguns lugares, os pressupostos feministas aceitam o desafio de que "a identidade é um mau sistema visual" (Haraway); em outros ainda "se estabelece de forma incontroversa a identidade das mulheres como pessoas com agenciamento" (Scott). Como diz Scott, sabemos que a diferença existe mas ainda estamos diante do desafio de entendê-la como constituída relacionalmente. Mesmo porque, como reclama Strathern, estamos também aprisionados a um modelo relacional que supõe que relações são relações entre entidades concretas e entre pessoas.

Assim, enquanto as pesquisas e discussões sobre (e entre) gênero e feminismo continuam lembremos o desabafo ainda nada anacrônico (para o bem e para mal) de Simone de Beauvoir sobre sua insatisfação quando, falando como intelectual, era interpelada naquele contexto dialógico em sua condição de mulher. Assim como a personagem Marianne que, lembremos também, desabafa dizendo: "no futuro, se qualquer um me explicar como eu sou — seja para me fragilizar ou para me tornar mais forte - eu não admitirei mais uma tal insolência". Essa é uma bela esquina onde podem, quem sabe, se encontrar, os estudos de gênero e as teorias feministas; as teorias, as análises, as leituras e os atos.

1 HANDKE, Peter. La femme gauchère. Paris: Gallimard, 1978, p. 34-35. Tradução minha.

${ }^{2}$ Escrita pelas organizadoras da coletânea.

${ }^{3}$ Escrito por Miriam Grossi.

\section{Transformações nas relações de gênero}

\section{Os Novos Desejos: Das academi- as de musculação às agências de encontros}

GOLDENBERG, Mirian (org.).

Rio de Janeiro: Record, 2000. 192p.

Os Novos Desejos, coletânea organizada pela antropóloga Mirian Goldenberg, reúne seis artigos que têm como proposta discutir as transformações nas relações de gênero, tomando como palco o dia a dia da cidade do Rio do Janeiro. O livro revela diferenças significativas nas formas pelas quais homens e mulheres vivem seus cotidianos, analisando valores e concepções que orientam práticas e visões de mundo dos universos sociais observados.

As questões que emergem dos estudos apresentados são relevantes para um entendimento mais abrangente da cultura brasileira, contribuindo, pela observação das diferenças de estilos de vida, para ampliar a discussão referente ao campo da antropologia urbana.

Além de dois artigos de sua própria autoria, Mirian Goldenberg trouxe a público quatro trabaIhos de alunos do Programa de Pós-Graduação em Sociologia e Antropologia do Instituto de Filosofia e Clências Sociais da Universidade Federal do Rio de Janeiro. Todos se destacam pelas qualidades inerentes às investigações de Goldenberg e a seus ensinamentos como professora de Metodologia Científica: a leitura do significado das relações sociais, o entendimento de valores e representações, a descrição das práticas em sua 
diversidade, o desenho de sistemas classificatórios, a captação do ponto de vista dos atores sociais nas redes da cultura.

São expressivos os problemas abordados, cuja atualidade e relevância se confirmam em distintas instâncias sociais. Parte das problemáticas científicas de prestígio, já legitimadas dentro da academia como objeto de estudo, as questões de gênero não mais preocupam exclusivamente o universo de militantes e feministas. Em torno das relações entre homens e mulheres existe um grande espaço de debate na mídia, e a diversidade dessas manifestações é indicadora de sua importância social.

A produção científica sobre gênero teve e tem grande impacto na desconstrução de estereótipos ligados a uma suposta essência ou natureza feminina. Situar a questão na especificidade do social, como a produção científica vem realizando, significa "desnaturalizar" os fenômenos, ou seja, mostrar que fatores como atitudes, comportamentos, gostos, relações entre homens e mulheres são fenômenos histórica e socialmente construídos e nada têm de naturais, pois pertencem ao campo da cultura e dos sistemas de relações.

O livro organizado por Mirian Goldenberg é parte desse debate e dessa história de investigações e, por isso mesmo, conduz o leitor a uma visão mais complexa e multifacetada da realidade. Vale frisar que parte das perguntas que conduzem os pesquisadores ao campo são universais e desde sempre fizeram parte do jogo e das inquietações teóricas ou existenciais. $\mathrm{O}$ que querem os homens e as mulheres? Quais as diferenças e semelhanças entre os desejos e as experiências de homens e mulheres? O que é ser mulher ? O que é ser homem?

Essas e outras perguntas direcionam o olhar do pesquisador para as tensões da convivência entre "novos" e tradicionais modelos de masculinidade e femininidade, causas das fricções e dos constrangimentos vivenciados na atualidade.

Discutindo as transformações de papéis entre homens e mulheres, os autores, através de descobertas e aproximações sucessivas, foram focalizando tanto as mudanças de valores quanto a permanência de outros que persistem, ambos igualmente atuais.

Dividindo o livro em duas partes, a autora discute, na primeira delas, a "(des) construção" do masculino, reservando a segunda parte aos papéis femininos, tanto no espaço público quanto no mundo privado. Depois de décadas de estudos preferencialmente dedicados às mulheres, obser- vamos hoje um interesse intenso sobre "o homem em crise". São matérias escritas em jornais e revistas que foram tomadas como empiria para a construção do objeto de pesquisa.

A pesquisadora circula igualmente bem tanto nas artes da observação participante quanto nas técnicas de pesquisa quantitativa. Advoga, inclusive, a importância de integrar na análise os dois métodos, tendo em vista maior compreensão dos fenômenos sociais, a partir dos cruzamentos de dados construídos pelo pesquisador. Essa é uma discussão atual sobre a qual, em outro momento (em A Arte de Pesquisar), foi do interesse da autora refletir.

No artigo "Um macho em crise", a pesquisadora analisa matérias de jornais e revistas de grande circulação, trazendo para sua análise dados da pesquisa que vem realizando desde 1998, que abrange aproximadamente 1300 homens e mulheres.

Concluindo o artigo, a autora esclarece que a década de 90 privilegia a reflexão sobre o homem, da mesma forma que em 60 e 70, esse privilégio pertenceu à mulher. A reflexão apresentada por Mirian Goldenberg gira em torno de uma temática que, segundo a pesquisadora, não pertence apenas ao contexto acadêmico, mas ocupa obsessivamente a mídia. A pesquisadora toma esses assuntos, recorrentes na mídia, imprimindo um outro tratamento, distante das análises apressadas. Por outro lado, é interessante registrar que a antropóloga é com muita freqüência convidada a debater esses assuntos, tanto na imprensa escrita quanto na televisa, para um grande número de pessoas fora das fronteiras acadêmicas. Merece destaque, portanto, o fato de que suas contribuições extrapolam os muros da universidade: assim, suas interpretações sobre a sexualidade, a conjugalidade e gênero são socializadas no contexto dos meios de comunicação de massa. Nesse sentido seu trabalho de pesquisa adquire uma dimensão sociocultural mais ampla, ao atingir um grande número de "leitores" que se apropriam de seus trabalhos.

Como serão interpretados seus argumentos e suas teses através das práticas leitoras desse público mais amplo, por definição heterogêneo, com suas competências diferenciais e específicas? Essa interrogação me leva a pensar em questões ligadas à teoria da leitura e problemas que eu mesma enfrento em minhas pesquisas atuais sobre a formação do leitor. Sem querer aprofundar, sinto, entretanto, que se coloca um problema interessante na linha da investigação sobre práticas leitoras. Roger Chartier diz que "não existe nenhum texto fora do suporte que o dá a ler, que não há 
compreensão de um escrito, qualquer que seja, que não dependa das formas através das quais ele chega ao seu leitor".

Uma das inúmeras perguntas que me ocorre poderia iniciar uma outra pesquisa. Como circula na sociedade a produção científica legitimada no interior da academia? Quais seus efeitos sobre as relações sociais?

Voltando ao primeiro texto de Mirian Goldenberg, quais os pontos emergentes? Como a chamada "crise da masculinidade" é percebida? Trata-se de crise ou de outra forma de viver os papéis masculinos? Outras possibilidades de exercício da paternidade e de direitos a serem conquistados pelos homens?

Mesmo sendo considerados casos restritos, é ampla a discussão sobre homens que lutam pela guarda de filhos e que cuidam deles sozinhos. A figura distante, violenta e não participativa de pai dá lugar à dimensão do afeto demonstrado, ao companheirismo, ao uso do tempo em função da dedicação maior aos filhos, mesmo que em detrimento de maior dedicação ao sucesso profissional e financeiro.

Esses valores não só aparecem através de exemplos citados na mídia como também são estimulados tendo em vista formas mais prazerosas de paternidade participativa. Como diz Mirian Goldenberg, entre outras constatações referentes às novas possibilidades de "ser homem" abrem-se alternativas de comportamentos mais descontraídos, como o uso de cosméticos, as operações rejuvenecedoras, os adereços. A modelagem do corpo é um caminho também aberto ao sexo masculino.

As alternativas postas são vividas por vezes com um certo pânico. As contradições e os valores conflitantes são interpretados por Mirian Goldenberg através da metáfora do "desmapeamento", utilizada por Sérvulo Figueira para indicar a coexistência de códigos contraditórios no sujeito, gerados no processo de modernização da sociedade. O moderno e o arcaico convivendo em níveis dissociados.

A antropóloga nega a versão de crise para os efeitos de mudança em curso. De fato não se pode mais pensar na hegemonia do típico machão, pois existem hoje muitas vias para o exercício da masculinidade. Nesse quadro, fica reiterada a hipótese de identidade de gênero como construção histórica e social.

Com o instigante título "De Amélias à operárias", a antropóloga apresenta um ensaio que visa a discutir os conflitos de mulheres economicamen- te ativas, tanto no mercado de trabalho quanto nas relações de conjugalidade. Pontos relevantes como o crescimento proporcional das mulheres economicamente ativas, a "feminização" da pobreza e a chefia familiar são analisados nesse texto em que Mirian Goldenberg comenta com agudeza as queixas tanto de homens quanto de muIheres sobre os efeitos perversos das transformações do papel da mulher.

Os conflitos entre os sexos são vistos como intensificados com a chamada libertação feminina. De um lado as mulheres reclamam da falta de homens e de outro os homens sentem-se pressionados pelas crescentes exigências femininas. A autora leva ao leitor outras idéias para a discussão das lutas entre os gêneros. No lugar das categorias tão caras às feministas, como a igualdade e os direitos da mulher, ela propõe o "respeito à diferença e ao espaço do outro, negociação diária, diálogo permanente, troca, crescimento mútuo". Essas são modalidades dos que reinventam a parceria amorosa, nos segmentos médios, a partir do cotidiano e não necessariamente tendo em vista a reprodução de grandes modelos sociais.

Os demais artigos incluídos no livro foram selecionados pela relevância de suas contribuições para a discussão de gênero. Marcelo Silva Ramos pergunta-se sobre "o que mudou e o que permaneceu em relação aos papéis de gênero", montando sua reflexão tendo em vista matérias veiculadas na mídia escrita. Ao comentar a suposta crise de identidade masculina, enfatiza a importância de associá-la às idéias de multiplicidade, plasticidade e flexibilidade de gênero. Cesar Sabino visa a compreender as representações sociais e práticas de freqüentadores de academias de musculação, apostando que tais práticas de construção do corpo são reprodutoras das desigualdades de gênero. Sua etnografia é feita em academias da zona norte da cidade do Rio de Janeiro, ressaltando aspectos das técnicas corporais utilizadas para a intervenção no corpo humano tendo em vista a produção de determinados padrões de estética, segundo um esquema classificatório que permite um olhar para o ethos masculino preponderante nas academias de musculação.

Erika Souza Vieira pesquisa as agências de encontros, cujos clientes buscam formas alternativas de busca de parceiros. Como funcionam essas agências? Quais os motivos que levam homens e mulheres a desistir das maneiras mais conhecidas de escolha de parceiros? Quais as operações sociais em jogo? Quem são os clientes e quais as suas expectativas? Seu trabalho não só 
produz conhecimento sobre o fenômeno em pauta como também contribui para as discussões relativas aos padrões de conjugalidade e para as reflexões sobre os estudos demográficos no Brasil, revelando outras faces da solidão feminina.

Renata de Melo Rosa tem como objetivo investigar o imaginário de gênero, trabalhando a questão do "parceiro desejável". Com essa indagação ela investigou doze mulheres, negras e brancas, moradoras da zona norte e oeste do Rio de Janeiro. Uma peculiaridade era comum a todas: desenvolverem relacionamentos afetivos com estrangeiros loiros e de olhos azuis. Símbolo de ascensão social, tal escolha passa por diferenças internas à constituição do casal analisado, considerando, entre outros aspectos, as questões "raci$\mathrm{al}^{\prime \prime}$, de gênero e de identidade nacional.

A qualidade das pesquisas apresentadas, a escrita acadêmica e ágil, a consistência das análises, a atualidade dos temas e a contribuição que o livro organizado por Mirian Goldenberg representa para os estudos de gênero faz de Novos Desejos leitura obrigatória para os pesquisadores da área e para todos aqueles curiosos sobre temáticas da atualidade da cultura brasileira.

TANIA DAUSTER 